IZA DP No. 8403

The Effect of Rehabilitative Punishments on Juvenile Crime and Labor Market Outcomes

Kristiina Huttunen

Sari Pekkala Kerr

Ville Mälkönen

August 2014 


\title{
The Effect of Rehabilitative Punishments on Juvenile Crime and Labor Market Outcomes
}

\author{
Kristiina Huttunen \\ Aalto University \\ and IZA \\ Sari Pekkala Kerr \\ Wellesley College \\ Ville Mälkönen \\ NIB \\ Discussion Paper No. 8403
August 2014 \\ IZA \\ P.O. Box 7240 \\ 53072 Bonn \\ Germany \\ Phone: +49-228-3894-0 \\ Fax: +49-228-3894-180 \\ E-mail: iza@iza.org
}

Any opinions expressed here are those of the author(s) and not those of IZA. Research published in this series may include views on policy, but the institute itself takes no institutional policy positions. The IZA research network is committed to the IZA Guiding Principles of Research Integrity.

The Institute for the Study of Labor (IZA) in Bonn is a local and virtual international research center and a place of communication between science, politics and business. IZA is an independent nonprofit organization supported by Deutsche Post Foundation. The center is associated with the University of Bonn and offers a stimulating research environment through its international network, workshops and conferences, data service, project support, research visits and doctoral program. IZA engages in (i) original and internationally competitive research in all fields of labor economics, (ii) development of policy concepts, and (iii) dissemination of research results and concepts to the interested public.

IZA Discussion Papers often represent preliminary work and are circulated to encourage discussion. Citation of such a paper should account for its provisional character. A revised version may be available directly from the author. 
IZA Discussion Paper No. 8403

August 2014

\section{ABSTRACT}

\section{The Effect of Rehabilitative Punishments on Juvenile Crime and Labor Market Outcomes*}

This paper estimates the effect of a rehabilitative punishment on the post-release outcomes of juvenile criminals using a unique Finnish data set on sentences and punishments merged with the longitudinal population census for 1990-2007. The rehabilitative program was aimed at improving the social skills and labor market attachment of young offenders aged 15 to 17 . A variety of research designs are used to isolate the effect of the juvenile punishment and to control for observable characteristics of the young offenders. The juvenile punishment experiment was initially conducted in certain criminal courts only and was applicable for youths aged under 18, giving rise to a differences-in-differences and triple differences setup. The juvenile punishment reduced reoffending during the year immediately after sentencing, but had no long-term effect on reoffending nor on labor market outcomes.

JEL Classification: K14, K42, J29

Keywords: juvenile crime, punishments, rehabilitation, recidivism, earnings, employment

Corresponding author:

Sari Pekkala Kerr

Wellesley College

106 Central Street

Wellesley, MA 02481

USA

E-mail: skerr3@wellesley.edu

\footnotetext{
* We gratefully acknowledge Yrjö Jahnsson Foundation for their funding to this project. We also thank all seminar participants at VATT, Hecer, UCL and Wellesley College for their helpful comments.
} 


\section{Introduction}

As a significant share of crimes is committed by adolescents, policies aimed at reducing juvenile crime are a critical component in the design of an effective criminal system that minimizes the social costs of crime. According to the UN statistics, over 16 percent of all criminal suspects in the U.S. were juveniles in 2002, altogether 1.4 million juvenile suspects. The rates are similar in the Scandinavian countries: In Sweden, almost 14 percent of all criminal suspects are juveniles, and in Finland almost 10 percent. The level of criminal activity tends to be at its highest in age groups 12 to 22, especially for offences such as theft and assault. The vast majority of crimes are committed by young, male offenders, and the criminals often originate from poor or otherwise disadvantaged family backgrounds (Freeman, 1999; Kaufman and Widom, 1999). These observations, coupled with the fact that previous offenders are likely to recidivate, imply that the prevention of criminal activity should focus on early criminal experiences.

While the social problems and costs related to juvenile crime are well understood, scholars argue about the best policies for rehabilitating young offenders. The expected severity of punishment has generally been shown to reduce offending (e.g. Levitt, 1998; Lee and McCrary, 2009; Drago, 2009), but once a person has already committed one or more crimes it becomes less clear whether stricter punishments can prevent further reoffending. Indeed, increasing the severity of punishments (e.g. longer incarceration) is associated with additional reoffending for those sentenced (Aizer and Doyle 2013; Durlauf and Nagin, 2011). Further, while recidivism is a key measure for the success of a criminal sanction scheme, a wider set of outcome measures, including education and employment, is needed to fully capture the overall effectiveness of punishments. This is particularly important for young offenders who choose between a criminal career versus obtaining more schooling and/or entry to the legitimate labor market. To date, the few studies that include labor market outcomes focus on prison sentences and adult offenders, and find that having been incarcerated has a negative effect on future employment (for a review, see Western et al., 2001). Conversely, conditional on being sentenced a marginal increase in the prison spell length may, in fact, be beneficial for offenders and improve 
their employment prospects (Kling, 2006; Landerso, 2012). ${ }^{1}$ Studies examining specific rehabilitative treatments offered within the prison system also focus on adult inmates (e.g. meta-analysis in Wilson et al., 2000), while much less attention has been given to their effectiveness for juvenile offenders.

This paper utilizes a juvenile punishment piloted in seven municipal courts in Finland in 1997-2004 to analyze the effectiveness of the new rehabilitative sanction on recidivism and the post-sentence socioeconomic outcomes of adolescent criminals ${ }^{2}$. The experiment introduced the new punishment designed for adolescents aged under 18 as an alternative to parole or juvenile prison. Our data include juvenile offenders living both in municipalities affected by the experiment and those not affected by the program, as well as criminals who were slightly too old to participate in the program in both types of municipalities. We use differences-in-differences approaches to disentangle the causal effect of the punishment on the subsequent criminal and other behaviors of the treated adolescents. ${ }^{3}$ The analysis is based on detailed micro data describing the criminal history and punishments of adolescents sentenced in 1990-2007. The crime data, merged with the population census, contain key socioeconomic information on the adolescents as well as their parents: family background characteristics, criminal history of the parents, education, and labor market outcomes. The data also allow us to follow the criminals for up to 10 years years their initial crime, making it possible to observe the dynamics of criminal and labor market outcomes. Such data have previously been unavailable to researchers.

As noted above, previous studies examining the effectiveness of punishments on reoffending and labor market outcomes have mostly focused on prison sentences and older criminals. The current study follows young offenders up to six years after their sentence

\footnotetext{
${ }^{1}$ This somewhat counter-intuitive finding may be explained by the fact that longer term inmates have more time to complete rehabilitative programs, which in turn helps curbing addictions and re-integrating to society.

${ }^{2}$ We use here the word "experiment" since this is how the juvenile punishment project was officially called. We could, however, call it a pilot project, since this was a new punishment that was first tested in certain pilot court districts. These courts were not randomly chosen.

${ }^{3}$ This research design allows the estimation of the "intention to treat effect", as well as the "average treatment effect on the treated".
} 
in order to see how the punishment affected reoffending and labor market careers. This is an important contribution to the literature, as we are not aware of any other study that had examined the medium- or long-term labor marker consequences of rehabilitative juvenile punishments. Here we show that the rehabilitative juvenile punishment does decrease the probability to commit property crimes in the year immediately following sentencing, yet despite its individually tailored content and a relatively intense schedule it has no systematic long-term effects on reoffending or on labor market outcomes.

This paper is organized as follows. The second section summarizes the previous economic and criminological empirical literature on juvenile crime and punishments. The Juvenile Punishment Experiment is described in the third section. Section four describes the Finnish data. Section five presents the empirical set-up and results, while the last section concludes the paper.

\section{Background and Previous Literature}

The effect of punishments on reoffending has interested economist for decades. Several studies document that the expected severity of punishments reduces reoffending both for juveniles (Levitt, 1998; Lee and McCrary, 2009) and for adults (Drago et al., 2009). This corresponds to the standard economic theory of Becker (1968) assuming that a person commits a crime if the expected gains from that crime exceed the utility that the prospective criminal would have derived from legitimate market activities. Another branch of literature tries to disentangle the effects of specific punishment types. The majority of these studies indicate that purely punitive sanctions (i.e. incarceration) are not necessarily helpful (Aizner and Doyle, 2013; Durlauf and Nagin, 2011). In contrast, many rehabilitative programs and punishments with rehabilitative components have proven more effective in curtailing future offending. Successful programs include drug treatment (Mitchell et al., 2009), transitional job programs such as the Center for Employment Opportunities (CEO) program (Zweig et al., 2010), work, education and vocational programs (Wilson et al., 
2000) ${ }^{4}$, interpersonal skills programs (Lipsey and Wilson, 1998; Hill et al., 2011), life skills training programs (Botvin and Griffin, 2004), as well as cognitive - behavioral programs (Landenberger and Lipsey, 2005; Tarolla et al., 2002). In the criminological evaluation literature the largest, consistently positive effects tend to be connected with programs including counseling and other behavioral therapy aimed at building interpersonal skills (see the survey by Lipsey et al., 2000). Employment related and academic programs have produced generally positive, if inconsistent effects, while deterrence programs, paroles and vocational programs have proven to be the least effective in reducing juvenile crime.

A series of studies has evaluated how incarceration affects labor market outcomes, finding large negative effects on employment and earnings (summarized in Western et al., 2001). However, studies that examine how the length of incarceration affects labor market outcomes find that a longer incarceration has a positive effect on employment and earnings (see Kling, 2006; Rasmussen, 2012). Both of these studies hypothesize that the possible mechanisms are related to the rehabilitative programs that the inmates participate in. In contrast, there is little research on rehabilitative punishments and labor market outcomes. As one exception, Zweig et al. (2010) find no short-term employment effects from a transitional job program for inmates. Indeed, while the criminological studies provide important insights into the effectiveness of various punishments and rehabilitation programs, their caveat tends to be their almost exclusive focus of re-offending as the outcome. The current study addresses these gaps by addressing the long-term labor market consequences of a rehabilitative juvenile sanction.

Much of the previous literature has concentrated on measuring the overall effectiveness of various punishments, but less headway has been made regarding the specific mechanisms through which the effects of punishments actually take place. As an example, some studies try to disentangle the overall effect of prison sentences into the incapacitation effect and the general deterrence effect (e.g. Shavell, 1987; Kessler and Levitt, 1999). Peer effects are an important yet difficult to measure factor when considering the effects of alternative punishments, and are likely to be an especially powerful mechanism for young offenders.

\footnotetext{
${ }^{4}$ Although critics such as Hill et al. (2011) point to other studies where the results from such programs have been equivocal at best.
} 
Indeed, Bayer et al. (2009) find significant peer effects in their study using data on juvenile prisons in Florida. Using separate evaluations against alternative comparison groups the current study can also touch upon the importance of potential peer effects.

To finish, there are additional special considerations for the analysis of juvenile crime. First, a large majority of juvenile crime is related to vandalism, traffic offences and violent behavior, where the monetary payoff is not particularly tangible (Jacob and Lefgren, 2003). Second, most of the young offenders have issues with alcohol and drug abuse, which also features in their decisions to commit crimes (CASA, 2004). And finally, juvenile criminals may be less likely to fully appreciate the negative consequences that a criminal past and dropping out of school have in terms of their future employment prospects. ${ }^{5}$ These factors suggest that providing juvenile offenders with means to overcome their substance abuse issues and helping them to better understand the consequences of their criminal activity may be effective in reducing recidivism and directing them towards more productive activities.

\section{Juvenile Punishment Experiment}

The juvenile punishment was introduced in 1997 as an experimental scheme in seven urban municipalities, containing about a third of the Finnish population and almost exactly the same proportion of the youth criminal activity. ${ }^{6}$ Originally the experiment was scheduled to run for three years, but was extended twice: first for two additional years (2000-2001), and then for three more years. The experiment continued until 2004, and eventually in 2004 the Juvenile Punishment Act (§1196/2004) was passed extending the juvenile punishment scheme into the entire country in January 2005.

The municipal courts were initially slow to adopt the experiment, and only applied it to cases where the young offender already had a previous criminal record containing at least one probationary sentence. The slow adoption pace of the new punishment led to

\footnotetext{
${ }^{5}$ In contrast, some studies have suggested that juveniles are no less sensitive to risk than young adults (e.g. Quadrel et al., 2000; Millstein and Halpern-Felsher, 2002a and 2002b)

${ }^{6}$ Juvenile Punishment Experiment Act $§ 1058 / 1996$.
} 
an amendment of the Juvenile Punishment Experiment Act in 1998. The objective of the 1998 Amendment was to broaden the application of the juvenile punishment to include those offenders who had yet to serve their first probation.

It should be pointed out that the pilot courts were not randomly selected among the 50 municipal courts in Finland, but were instead chosen with the aim to guarantee a large enough number of potential participants in the juvenile punishment. Therefore large urban regions are somewhat over-represented among the pilot courts. ${ }^{7}$ The pilot municipal courts were Espoo, Helsinki, Joensuu, Tampere, Turku, Vaasa and Vantaa, three of which are located in the greater Helsinki area and all of which are in the top-15 in terms of their population size. While many of the largest cities are among the pilot areas the comparison group also includes several larger cities, including Oulu, Jyvaskyla, Kuopio and Lahti. Below we explain how we deal with the non-random selection of municipal courts into the pilot scheme in our econometric estimation.

According to Marttunen and Takala (2002), by the end of 2001 around 60 young offenders had been sentenced to juvenile punishment each year. This corresponds to about 20 percent of the probations sentenced to the young offenders in the experimental municipalities. Indeed, the 1998 Amendment triggered a significant increase in the use of the juvenile punishment by the municipal courts. During 1997-2004 a total of 404 juvenile punishments were given, while the number of punishments reached 114 in 2005-2008. This represents about 5 percents of all sentences (excluding fines) given to offenders aged under 18 in 1997-2004, and roughly 4 percent thereafter.

\subsection{Target Group, Objectives and Implementation of the Juve- nile Punishment}

According to the Law on Juvenile Punishment, criminals aged 15-17 can be sentenced with the juvenile punishment if imprisonment is considered to be too severe and a fine too

\footnotetext{
${ }^{7}$ Of course, given the dominance of the greater Helsinki region in terms of its population share it would be difficult to design any experiment at the municipal court level that would perfectly balance the treatment and control groups in this respect.
} 
lenient a punishment. In severity, the juvenile punishment is regarded comparable to a probation, although in practice it is a more intensive punishment as described below. The length of juvenile punishment can vary from four months to a year, while the maximum probation length is two years.

The juvenile punishment was intended to be a very rehabilitative program where the contents could be targeted to fit the offender's needs, and its aim was to better integrate the young offenders to society and prevent involvement in further criminal activity. ${ }^{8}$ The components include motivational discussions, counseling aimed at problem solving and crime prevention, social skills training, anger management, traffic education, a substance abuse segment and a program aimed at increasing the connection to society. At the onset of punishment, each offender is evaluated and a detailed plan of action is constructed, taking into account the specific issues faced by the offender.

The anger management and substance abuse programs were most commonly used as these are pervasive issues that the young offenders struggle with. The average number of service hours ordered was 34 , and the average length of supervision was eight months. Of the rehabilitative components, most time was spent on the crime prevention counseling (49\%) followed by the substance abuse and motivational discussions (25\%) and anger management (12\%) (Keisala and Marttunen, 2007). To summarize the typical content of the juvenile punishment, the various program components attended by the young offenders were as follows:

$100 \%$ Two weekly meetings with program officer (3 hours / week)

$100 \% \quad$ Crime prevention program

$66 \% \quad$ Substance abuse and motivational programs

$60 \% \quad$ Introduction to working life

$50 \% \quad$ Anger management program

$33 \% \quad$ Other rehabilitative programs

The Act contains provisions for cases where the offender neglects to adhere to the conditions of the enforcement plan. If the person sentenced to juvenile punishment violates

\footnotetext{
${ }^{8}$ The contents of the program along with detailed instructions for each component are discussed in the Juvenile Punishment Handbook (2005).
} 
the enforcement plan, the Probation Service would first serve him a written warning. In the case of more serious violations, such as interrupting the punishment, a report is prepared for the prosecutor in the matter who may then take the case back to court. A typical sanction for a serious violation of the enforcement plan is a probation, supplemented (in about one half of the cases) with a fine. ${ }^{9}$

Compared to the alternative punishments, probation and juvenile prison, the juvenile punishment clearly included more rehabilitative components and more intensive supervision. Probation sentences do not include any supervision meetings with a program officer unless deemed necessary by the judge, and even then the meetings primarily occur at the beginning of the program. ${ }^{10}$ Probations also do not include any rehabilitative components within the program. Based on interview responses in previous studies, the young offenders do not perceive probations as a significant punishment (Ekblom and Lahtinen, 2007), apart from an increased threat of a more severe subsequent punishment in case of re-offending.

The other alternative to the juvenile punishment is a sentence in juvenile prison. While a juvenile prison sentence could in principle include rehabilitative components, these programs are not widely offered but prisoners have to actively seek to be admitted. It is possible to continue high-school or comprehensive school education while in prison by completing book exams, but no actual tuition is offered. The most negative effect of a prison sentence likely accrues through the peer effects, as the peer group in prison includes criminals with considerable criminal histories (Hemilä, 2007).

While both probation and prison sentences include fewer rehabilitative elements than the juvenile punishment, their respective effects relative to juvenile punishment may still be very different due to the types of criminals involved and the peer groups the offenders are exposed to. To evaluate that possibility, the effect of juvenile punishment is estimated

\footnotetext{
${ }^{9}$ The interruption percent was relatively high during the juvenile experiment experiment phase (19972004), about 30 percent.

${ }^{10}$ Only a third of the youths aged 18 to 20 had supervision as part of their probation, while two thirds of those aged 15 to 17 met with supervisors (Marttunen, 2004). The intensity of supervision was lower in probation sentences $(<1$ meeting per month) relative to the juvenile punishment (2 meetings per week).
} 
against either of the two alternative punishments both jointly and separately.

In terms of its cost to society, the expenses related to the implementation of an average juvenile punishment were 10 thousand euros per punishment in 2009 (Rikollisuustilanne 2009). This is clearly more than the cost of a typical probation $(€ 3,793)$, but noticeably less than the cost of a juvenile prison sentence $(€ 21 \mathrm{k}$ to $€ 31 \mathrm{k})$. The lower cost relative to prison sentences is partly related to the shorter average length of the juvenile punishment, but even if calculated on a daily basis the prison sentences carry a much greater cost.

\subsection{Offences and Recidivism}

The most common offences sentenced with the juvenile punishment are various assaults, violence and thefts, all of which are prevalent offences among young adults. Indeed, the most common offences sentenced with the two alternative punishments (probation or juvenile prison) were also most commonly the exact same types of crime. In addition, young offenders are likely to commit multiple crimes even before facing their first serious sanction. About two thirds of the offenders receiving a juvenile punishment had at least one prior probation and the average offender had two or three prior sentences, including fines and community service (Marttunen and Takala, 2002).

The initial statistical analyses of the juvenile punishment experiment gave a very pessimistic view of its effectiveness in preventing recidivism. For example, Marttunen and Takala (2002) concluded that during a twelve-month follow-up period, at least 57 percent of the youth sentenced to a juvenile punishment committed a new offence for which they received at least a probation. On average, the young offenders committed 7.7 new registered offences during the 12 months following their first juvenile punishment. However, the authors of the study admit that they had not considered any comparison groups, nor did they control for other background factors that might affect the level of criminal activity and recidivism in the treatment group. In addition, besides recidivism, prior evaluations of the juvenile punishment experiment did not consider other potential effects of the program. The current study attempts to address those shortcomings by creating a sophisticated treatment - control setup and will also evaluate a greater variety of 
post-sentence outcomes, including education and labor market attachment.

\section{Finnish Data and Crime Statistics}

To estimate the effect of the juvenile punishment on recidivism and other outcomes we use longitudinal data on individual criminal activities between 1990 and 2007 maintained by Statistics Finland. The data on criminal activities and punishments have been merged onto the longitudinal population census, which contains information on the offenders' background, as well as annual data on pre-conviction and post-release activities. In addition, we have macro data on criminal activity and policing by municipality. Compared to the data used in most previous studies, the Finnish micro data provide a unique source of information on the criminal history and socioeconomic background of individuals with a criminal record.

The annual population census file consists of detailed demographic information, including the persons' age, gender, residential area, education and labor market status, as well as various indicators of family background. The crime database includes aggregate data on crime rates by the type of crime and location, criminal activity reported in the region as well as the percentage of crimes solved by the police. In addition, the individual level crime data reveal the dates and locations where each crime took place, as well as the associated convictions and the nature of the punishments received. As for the parents of the young offenders, the data also include information on whether either parent had ever been sentenced to prison or parole.

The data covers approximately $90 \%$ of all male offenders. ${ }^{11}$ For each person we observe their entire criminal history, including all past crimes and the corresponding punishments during the period 1990-2007. In the case of most offenders, we observe several crimes resulting in sanctions. Therefore, the crimes are categorized as 1) the principal crime resulting in the punishment and 2) additional crimes that were secondary grounds for the

\footnotetext{
${ }^{11}$ Female offenders are excluded from the data. According to Statistics Finland, they represent 18 percent of all criminals in the 15-20 age category. Only 2 percent of those sentenced to juvenile punishment were female.
} 
same punishment.

The rationale for constructing the samples for the empirical analysis is as follows. The juvenile punishment was designed for young offenders for whom imprisonment was considered to be too severe and a fine too lenient a punishment. According to the case documents, the judges often felt that juvenile punishment was a slightly harsher punishment than probation. Thus the group of individuals who were actually sentenced to the juvenile punishment may be negatively selected from the group of all individuals eligible for this punishment. On the basis of this target group for the juvenile punishment we argue that a plausible comparison group consists of those offenders whose sanction was either a probation, a spell of community work or a short (less than one year) imprisonment. We restrict the data to these sentences. ${ }^{12}$

Since the focus is on young offenders, we further restrict the sample to offenders that committed crimes when they were 15-19 years old. In the analysis we split the data to two age groups: 1) offenders eligible for juvenile punishment (aged 15 to 17 at the time when they committed a crime), and 2) young offenders no longer eligible for juvenile punishment (aged 18-19 at the time of the crime). The data is further divided into individuals who received a sanction in a municipal court located in one of the seven experimental municipalities, and those individuals who received their sanction from a non-experimental municipal court. Therefore, the potential treatment group consists of those offenders who were 15-17 years old at the time of the crime and received a sanction in one of the seven experimental municipal courts. We focus on individuals who were sentenced during 19912004 and follow their criminal activities and socioeconomic outcomes for a maximum of six years after the punishment using data for years 1990-2007.

Table 1 reports the distribution of the sentences and related main crimes in the sample. ${ }^{13}$ Probations (with or without fines) are by far the largest category of all sanctions in the sample, while juvenile punishments are the smallest category. Property crime is the dominant offense in all punishment groups and probation is the most typical sanction

\footnotetext{
${ }^{12}$ As a further robustness check, the analysis is also performed separately against those offenders who were sentenced to prison versus probation.

${ }^{13} \mathrm{We}$ restrict the analysis only to the principal crimes resulting in a sanction.
} 
applied to such offenders. Figure 1. shows the number of juvenile punishments by year in our data set. The share of the juvenile punishments in the eligible group (15-17-yearold individuals sentenced in experimental municipal courts) was $14 \%$ during the period 1997-2004. The take up rate varies from year to year, maxing out in 2000 (24\%).

Table 2 reports the means of the background characteristics for the treatment and control groups before and after the Juvenile Punishment Experiment Act took effect in 1997. There are no obvious, large differences across the groups that could not be explained by differences in the offenders' age or location, and therefore accounted for by the fixed effects included in the regression analysis. However, comparing the means of the background characteristics for the group that was actually sentenced to juvenile punishment shows that among the eligible individuals those sentenced were a very selected group.

The macro data on crime rates by municipal court shows that the experimental municipalities did have somewhat higher rates of criminal activity relative to other municipalities in 1997. The average annual crime rate measured as crimes per capita was just under $15 \%$ in the experimental municipalities, compared to just under $13 \%$ in other municipalities. This further indicates that the estimated model should include fixed effects for experimental locations, to control for any time invariant factors affecting criminal activity. In addition, fixed effects for age groups are required to control for any differences in criminal participation across age groups. The number of crimes considered in municipal courts per the size of the age cohort is about 0.17 in the $15-17$ age group and 0.34 for the $18-20$ age group.

\section{Research Design}

\subsection{Differences-in-Differences Set Up}

To evaluate the effect of the rehabilitative juvenile punishment on post-program outcomes, we first adopt a differences-in-differences approach that allows for controlling both the regional fixed effects as well as any time trends. To be more specific, we estimate the equation using a sample of young offenders (i.e. 15-17-year-olds) 


$$
Y_{i j t+k}=\alpha+\beta_{1} X_{i j t}+\beta_{2} \text { Year }_{t}+\beta_{3} \text { Pilot }_{j}+\beta_{4} \text { Age }_{i}+\beta_{5} \text { After }_{t} \text { Pilot }_{j}
$$

where $\mathrm{i}$ is the individual, $\mathrm{j}$ is the municipal court where the individual was sentenced and $\mathrm{t}$ is the year of sentencing. $Y_{i j t+k}$ is the outcome, most typically an indicator variable for whether the individual re-offended during the $k^{\text {th }}$ year after sentencing. The vector of control variables $X_{i j t}$ includes any pre-sentencing characteristics of the individual and his family that might capture systematic differences between our control and treatment groups. In particular, the vector includes indicators for having no father or mother present, growing up with a single parent, having either or both parents died, having a parent with criminal history, whether parents worked, had positive earnings, and whether parents had obtained any secondary or higher education. ${ }^{14}$ In addition, $X_{i j t}$ includes information on the offenders' own status at the time of committing the crime (at school, living at home, number of siblings, previous criminal offences), as well as the municipality of residence (unemployment rate, urban environment and the proportion of crimes that are solved by the police), and the type of crime for which the individual was sentenced (violent, prison, traffic, drug, other).

Most importantly, Year $_{t}$ is an indicator variable for the year, $A g e_{i}$ is the age at the time when the individual committed the crime, and Pilot ${ }_{j}$ is an indicator for being sentenced in an experimental (pilot) municipal court. These, respectively, control for any common post-period shocks, permanent differences between older and younger individuals and permanent differences between experimental and non-experimental municipalities. The interaction After $_{t}$ Pilot $_{j}$ controls for the time specific shocks that affect the outcomes of individuals sentenced in experimental courts. This coefficient gives us the DD estimator. The key identifying assumption is that there are no contemporaneous shocks that affect the relative outcomes of the young offenders sentenced in pilot locations differently than other young criminals.

\subsection{Triple Differences Set Up}

\footnotetext{
${ }^{14}$ These control variables are chosen as numerous previous studies have shown that issues with home environment are highly correlated with the probability of being involved in criminal activity (see e.g. Cummings et al., 2000; Hess and Orthmann, 2010).
} 
In order to control for other time specific shocks that affect all criminals sentenced in pilot locations we also adopt a triple differences approach that allows for controlling both the regional fixed effects as well as the age group fixed effects and any time trends. To be more specific, we estimate the following equation using data on younger (15-17) and slightly older (18-19) offenders.

(2) $Y_{i j t+k}=\alpha+\beta_{1} X_{i j t}+\beta_{2}$ Year $_{t}+\beta_{3}$ Pilot $_{j}+\beta_{4}$ Age $_{i}+\beta_{5}$ Pilot $_{j}$ Age $_{i}+\beta_{6}$ Year $_{t}$ Pilot $_{j}+$ $\beta_{7} y$ Year $_{t}$ Age $_{i}+\beta_{8}$ After $_{t}$ Pilot $_{j}$ Young $_{i}$

where $\mathrm{i}$ is the individual, $\mathrm{j}$ is the municipal court where the individual was sentenced and $\mathrm{t}$ is the year of sentencing. The interaction $\mathrm{Pilot}_{j} A g e_{i}$ takes care of any time-invariant characteristics of the treatment group, while Year $_{t}$ Pilot $_{j}$ controls for the time specific shocks that affect the outcomes of individuals sentenced in experimental courts. Finally, $Y_{\text {ear }} \mathrm{Age}_{i}$ captures the common time-specific shocks to young individuals. The coefficient of interest, $\beta_{8}$ (the third level interaction), captures all variation in the outcome variable specific to 15-17 year old criminals $\left(Y_{\text {oung }}\right.$ ) sentenced in pilot municipal courts after the introduction of the juvenile punishment (years 1997-2004). This coefficient gives us the "triple-differences" (DDD) estimator. The key identifying assumption is that there are no contemporaneous shocks that affect the relative outcomes of the treatment group differently than other young criminals or older criminals in the experimental municipalities.

\subsection{Propensity Score Pre-screened Difference-in-Differences or Triple Differences}

The individuals sentenced to juvenile punishments differ greatly in terms of their presentencing characteristics from all eligible offenders (see Table 2). Since the dynamics of the outcome variables may differ between individuals that have a higher propensity to be sentenced to juvenile punishment, we also adopt an alternative strategy. We estimate the probability to be sentenced to juvenile punishment for eligible offenders (15-17 years old in pilot courts) using a rich set of pre-sentence characteristics $X_{i j}$ as described above. We then calculate the estimated probability of receiving juvenile punishment for all individuals using the estimated propensity score $P\left(X_{i j}\right)$. We use this propensity score to trim our 
estimation data and estimate the difference-in-differences or triple differences model using a sample where we exclude observations for which the probability to receive treatment is lower than 0.1. (See Crump et al., 2009). We also experimented by weighting the data with $P\left(X_{i j}\right)$ so that individuals with higher propensity for being sentenced to juvenile punishment receive a higher weight $\left(P\left(X_{i j}\right) / 1-P\left(X_{i j}\right)\right)$, and those who were actually sentenced receive a weight of $1 .^{15}$

\section{Results}

\subsection{Effect of juvenile punishment on reoffending and labor mar-}

\section{ket outcomes}

The most typical outcome variable analyzed in these "effectiveness of punishments" studies is the probability of re-offending. The current study, however, attempts to take a broader view at the potential effects of the juvenile punishment system. In particular, the available data allows the analysis of both crime related outcomes as well as numerous labor market and educational outcomes. These may be particularly informative for the young offenders as many of them eventually do exit the crime cycle, unlike their more seasoned compatriots. The outcomes of interest are estimated year by year, from year 1 until year 6 post-sentencing. The first set of results (figure 4 and table 3 ) uses young offenders sentenced to either juvenile prison or probation as the comparison group, but separate estimates against each alternative punishment are reported at the end of this section. Since the outcome variables vary at the individual-level we collapse the sentence-level data to individual-year level. ${ }^{16}$

\footnotetext{
${ }^{15}$ This is a way to obtain an estimate that equals the average effect of treatment on the treated (ATT). In order to obtain the average effect of treatment on all one should weight the data using the inverse of the score (see Imbens et al., 2001)

${ }^{16}$ We repeated the analysis at sentence-level and found very comparable results.
} 
Figure 4 (and table 3) plots the difference-in-differences estimates of the effect of juvenile punishment on probability to commit crime by each post-sentence year 1 to 6 . The figure also plots the $95 \%$ confidence intervals around the estimates. The results indicate that the juvenile punishment did not reduce the probability of re-offending in general. It had however a small, although imprecise, negative effect on the probability to commit a property crime in the year immediately after sentence. The reduction in the likelihood to commit property crime was 4.3 percentage points in the year immediately following the sentence. This corresponds to a $10 \%$ decrease, when compared with the probability of committing property crime by the first post-sentence year $(40 \%)$ in the sample. ${ }^{17}$ For later years the estimates are rather imprecise although the sign of the coefficient remains negative. It is important to note that the outcome information for years 4,5 and 6 is not available for the later sentences since the latest year for which we observe outcomes is 2007. We report the results for a balanced panel (1991-2001 sentences) in appendix figures A1 and A2, where we follow the same individuals from sentencing until year 6 . The estimated effects using the earlier years only were very similar to those from the full 1991-2004 sample.

Figure 5 reports the results for labor marker outcomes. For young offenders one of the most interesting outcomes is the probability of returning to (or continuing at) school and/or receiving a secondary or tertiary education degree. Very few of the offenders under the age of 17 had any formal degree at the time of committing the crime. The estimated effects of the juvenile punishment on the probability of obtaining post compulsory education are essentially zero.

Entry into the labor force and employment are also crucial outcomes characterizing the success of the juvenile punishment experiment in moving the young offenders to a more productive lifestyle. Obviously very few of the criminals under the age of 17 had real any work experience prior to sentencing: less than 10 percent were working at the time of sentencing. By year 6 almost 35 percent of the sample were employed. ${ }^{18}$ We would not

\footnotetext{
${ }^{17}$ The sample means of all outcome variables are reported in appendix table A1.

${ }^{18}$ This does not include part-time employment of students, but is based on the individuals' main economic activity during the year.
} 
necessarily expect the juvenile punishment to immediately increase the employment of the very youngest participants as they would still be completing their compulsory schooling. ${ }^{19}$ Perhaps related to this, the estimated effect of the juvenile punishment on employment is never significantly different from zero. There is also no long-term effect on the probability of unemployment or being outside of labor force.

We ten estimated the effects on taxable real income (reported in table 3), which includes certain taxable benefits such as student grants and unemployment benefits. The estimated effect is not significantly different from zero, and if anything appears to be negative. Compared to the other outcomes of interest our priors regarding the direction of the income effects are less obvious. On one hand, if the juvenile punishment experiment significantly increases the probability of staying in school this would tend to lower any observed earnings during the time spent studying. On the other hand, if the probability of employment and the level of human capital related to educational degrees are later increased as a result of the program then earnings might be increased too. Perhaps due to these counter-balancing effects the double differences estimates show no significant effect on annual taxable income.

Figures 6 and 7 (and table 4) report the results of the triple differences model. The advantage of the triple differences strategy is that we can take into account all other time specific shocks that might have affected the outcomes of offenders in pilot locations. Since the pilot court districts were not randomly chosen it is possible that offenders in those districts may also be different in terms of the dynamics of the outcome variables. In order to control for time specific shocks affecting pilot locations we estimate the model using both younger and slightly older age groups, and control for the time specific shocks affecting all workers in pilot locations, as well as time specific shocks affecting all younger offenders across locations. The results show a similar, although a slightly smaller, reduction in the probability of reoffending. This indicates that the effect on property crime was not driven by any overall decrease in the property crime rates in pilot locations.

\footnotetext{
${ }^{19}$ Finland mandates the completion of a nine-year comprehensive school by all students. The usual age at completion is 16 , although a small part of the age cohort attend the 10th class and graduates from the comprehensive school at age 17 .
} 
Interestingly the triple differences specification now indicates a positive effect on employment in the fourth and sixth year after sentencing. Given the low level of employment in the sample of young offenders (34\%), an increase of 7 percentage points by year 4 can be considered a rather large impact ( $20 \%$ increase). We remain somewhat cautious when interpreting this estimate as a direct effect of juvenile punishment, since it appears to be mainly explained by the fact that employment of older criminals in non-pilot locations increased more than the employment of older criminals in pilot locations (Figure 3). The effects on the probability of non-participation are negative, although significant only in year three. Overall, the pattern of estimates related to the labor market outcomes indicates that the juvenile punishment had at most some scattered desirable effects on the treated population.

In order to further investigate whether the reoffending results are indeed driven by the juvenile punishment instead of other time-specific events we report in Figure 8 the point estimates of a model that estimates the difference between the treatment group (young offenders in pilot locations) and comparison group (young offenders in non-pilot locations) year by year before and after the introduction of the juvenile punishment. The figure plots the pilot*year interaction in a model that estimates the effect on reoffending probability. The results show that in those years when the largest number of juvenile punishments were given (e.g. 2000) there was also a drop in the difference between reoffending rates of the treatment and comparison groups. This finding further supports our identification strategy.

Thus far we have been reporting the intent-to-treat estimates. In order to capture the magnitude of the effect on the treated individuals we report in table 5 the instrumental variable estimation results where the eligibility for juvenile punishment is used as an instrument for being sentenced to the punishment. In the difference-in-differences set up the eligibility is captured by the interaction pilot*after, and in the triple differences specification by the three-way interaction pilot*after*younger. Otherwise the controls are the same as reported before. The IV estimation results using sample of younger workers indicate that juvenile punishment decreased property crime by 27 percentage points. Given that the average probability to commit property crime by year $t+1$ in the sample is $40 \%$ 
this corresponds to a $67 \%$ decrease in the probability to commit property crime.

\subsection{Results using alternative comparison groups}

In order to better understand the mechanism through which the juvenile punishments affects the offenders' outcomes we estimated the model for reoffending separately against the two alternative punishments (probation and prison). The results in Table 8 indicate a much stronger decrease in repeat crime rates when using data on prison sentences and juvenile punishments only. However, the immediate negative effect on property crime remains for the probation versus juvenile punishment comparison also. In both cases the estimates stay negative but become insignificant over time.

One reason for the more sizeable reduction in reoffending when comparing the juvenile punishment to the prison group may be related to the peer effects that the young offenders are exposed to in prison. Interviews with criminals sentenced to juvenile prisons in Finland indicate that prisons certainly have an element of being "schools for criminals" (e.g. Hemilä, 2007). Likewise, in their study of Florida juvenile prisons Bayer et al. (2009) also find significant peer effects for many of the types of crime that we are considering here. On the other hand, the two main differences between probation and the juvenile punishment are related to rehabilitation and peer effects. While a probation includes few rehabilitative measures and barely changes the peer group that the young offenders are exposed to, juvenile punishments include by design a more intensive set of rehabilitative components (as discussed earlier). In addition, the "introduction to working life"-component and the more frequent meetings with the program counselor also provide a new set of peer and

other inter-personal influences that do not exist for the probation population. As we do not have data on the specific components that each of the juvenile punishments included we unfortunately cannot further disentangle the mechanisms creating the overall effects.

\subsection{Robustness checks and extensions}

To conclude, we performed a number of additional robustness checks to test our results. In Appendix Tables A3 and A4 we use the propensity score pre-screened sample. The 
idea of the propensity score pre-screening (or weighting) is that individuals sentenced to juvenile punishment differ from other criminals in terms of their observable characteristics and these differences may be related to the dynamics of the outcome variables. Table A2 reports the effect of background variables on the probability to be sentenced to juvenile punishment (propensity score). The table confirms that individuals sentenced to juvenile punishment differ greatly by observational characteristics from the eligible population. The estimated negative effect on property crime slightly decreases in the propensity score pre-screened sample, somewhat contrary to what we expected since by pre-screening we also increased the share of individuals sentenced to juvenile punishment among the eligible from $14 \%$ to $17 \%$. Interestingly, the positive employment effect decreases even more in the pre-screened sample, which again sheds doubt on whether we can interpret it as a causal effect of the juvenile punishment.

As other robustness checks we also tried including group specific trends, and found that it had no effects on the results. We also checked whether the effects varied across age groups $(15,16$, and 17). The intent to treat effects were higher for older age groups, a finding that can be explained by a higher take-up rate. In addition, we experimented with clustering the standard errors at the treatment level and found that the effects on property crime remained significant. Finally, we repeated the analysis at the sentencelevel rather than the individual-level. The results were very similar, but the propensity score pre-screened results indicated somewhat stronger reductions in reoffending. Based on these checks we argue that our main finding related to the effect on property crime is very robust, and the lack of other effects also persists through a variety of analyses.

\section{Conclusion}

We estimated the effect of a new, rehabilitative punishment on the post-release outcomes of juvenile criminals using a unique data set on sentences and punishments. The experiment created a situation where otherwise similar criminals were not assigned the juvenile punishment if they were living in municipalities that were not part of the experiment or if they were slightly too old to be eligible. We used a difference-in-differences and a triple 
differences approach to estimate the "intention to treat effect", as well as the "average treatment effect on the treated.

Regardless of the much more rehabilitative nature of the new punishment and its individually tailored content we find that the juvenile punishment had at most modest and not very enduring effects on reoffending. Likewise, we find small and mostly insignificant effects on schooling and labor market outcomes. The negative effects on reoffending are larger when comparing against the offender population that was sentenced to juvenile prison and therefore exposed to a more criminal peer group. In that sense our results are in line with the study of Bayer et al. (2009) who find negative peer effects in Florida juvenile prisons for many of the same types of crimes as those studied here.

Our study contributes to the existing literature in several ways. First, it is a novel attempt to analyze the effect of a tailored rehabilitative punishment on juvenile crime using a quasi-experimental setting. In addition, it sheds light on the education and labor market consequences of the sentence in the short, medium and long term. Moreover, this study provides an example of combining crime and punishment data with administrative register data where a much wider set of background characteristics and economic outcomes can be observed for the full criminal population. This allows for a much more detailed effectiveness analysis than is typical in studies of crime. Finally, while we found few significant effects of the rehabilitative program overall, it is possible that certain individual components of the program might have been more effective than others, and certain subgroups of the offenders might have benefitted more than others. Our current data do not permit analyses at such level of detail, but as more detailed data become available and as more juvenile criminals go through the program, future studies can further disentangle the rehabilitative effects.

\section{References}

[1] Aizer, A. and J. Doyle (2011), Juvenile Incarceration \& Adult Outcomes: Evidence from Randomly-Assigned Judges, memo 
[2] Bayer P., Hjalmarsson R. and Pozen D. (2009) Building Criminal Capital behind Bars: Peer Effects in Juvenile Corrections. Quarterly Journal of Economics, 124: 1, 105-147.

[3] Becker G.S. (1968) An Economic Approach to Crime. Journal of Political Economy, 76: $2,169-217$

[4] Bloom H., Orr L.L., Cave G., Bell S.H., Doolittle F. and Lin W. (1994) The National JTPA Study: Overview of Impacts, Benefits and Costs of Title IIA. Abt Associates, Cambridge, MA.

[5] Botvin G.J., Griffin K.W. (2004) Life-Skills Training: Empirical Findings and Future Directions. The Journal of Primary Prevention, 25: 2: 211-232

[6] Botvin G.J., Griffin K.W. and Nichols T.D. (2006) Preventing Youth Violence and Delinquency Through a Universal School-Based Prevention Approach. Prevention Science, 7: 4, 403-408

[7] Bound J. and Freeman R.B. (1992) What Went Wrong? The Erosion of Relative Earnings and Employment among Young Black Men in the 1980s. Quarterly Journal of Economics, 107:1, 201-32.

[8] BSF Handbook (2004) Beteende Samtal Förändring - BSF. Kriminalvården. Norrköping.

[9] CASA (2004) Criminal Neglect: Substance Abuse, Juvenile Justice and the Children Left Behind. The National Center on Addiction and Substance Abuse at Columbia University.

[10] Bushway S.D. (1996) The Impact of a Criminal History Record on Access to Legitimate Employment. Mimeo. Carnegie Mellon University, Pittsburgh, PA.

[11] Chen M.K. and Shapiro J.M. 2007. Do Harsher Prison Conditions Reduce Recidivism? A Discontinuity-Based Approach. American Law and Economic Review: 9, 1-29. 
[12] Corman H. and Mocan H.N. (2000) A Time-Series Analysis of Crime, Deterrence, and Drug Abuse in New York City. American Economic Review, 90: 3, 584-604

[13] Cummings E.M., Davies P.T. and Campbell S.B. (2000) Developmental Psychopathology and Family Process: Theory, Research, and Clinical Implications. Guildford, New York.

[14] Donohue III J.J. and Levitt S.D. (2001) The Impact of Legalized Abortion on Crime. Quarterly Journal of Economics, 116: 2, 379-420

[15] Drago F., Galbiati R. and Vertova P. (2009) The Deterrent Effects of Prison: Evidence From a Natural Experiment. Journal of Political Economy, 117: 2, 257-280.

[16] Durlauf S. and Nagin D. (2011) Imprisonment and Crime: Can Both Be Reduced? Criminology and Public Policy, 10: 1, 13-54.

[17] Ekblom H. and Lahtinen S. (2007) Kai sita yritetaan nuorille puhua, etta jutella asioista, elamasta, tulevaisuudesta: Ehdollisesti rangaistujen nuorten ajatuksia valvontatyosta Kriminaalihuoltolaitoksen Jyväskylän aluetoimistolla. Opinnäytetyö. Jyväskylän Ammattikorkeakoulu 2007.

[18] Fagan J. and Freeman R.B. (1999) Crime and Work. In Tonry M. (Ed.) Crime and Justice: A Review of Research. Chicago: University of Chicago Press, Vol. 25.

[19] Freeman R. (1999) Disadvantaged Young Men and Crime. In Blanchflower D. and Freeman R. (Eds.) Youth Employment and Joblessness in Advanced Countries. Chicago: University of Chicago Press.

[20] Glaeser E.L., Sacerdote B.I. and Scheinkman J.A. (2003) The Social Multiplier. Journal of the European Economic Association, 1: 2-3, 345-353

[21] Goldstein A.P., Glick B., Reiner S., Zimmerman D., Coultry T.M. and Gold D. (1987) Aggression Replacement Training. A Comprehensive Intervention for ActingOut Delinquent. Journal of Correctional Education, 37, 120-126. 
[22] Goldstein A.P., Glick B. and Gibbs J.C. (1986) Aggression Replacement Training: A Comprehensive Intervention for Aggressive Youth. Research Press, Champaign, IL.

[23] Grogger J. (1995) The Effect of Arrests on The Employment and Earnings of Young Men. Quarterly Journal of Economics, 110: 1, 51-71

[24] Halpern-Felsher B.L. and Millstein S.G. (2002) The Effects of Terrorism on Teens' Perceptions of Dying: The New World Is Riskier Than Ever. Journal of Adolescent Health, 30: 5, 308-311

[25] Hemilä (2007) Lusiminen on kuntoutumisen vastakohta. Pro-gradu tutkielma. Jyväskylän yliopisto.

[26] Hess K.M. and Orthmann C.H. (2010) Criminal Investigation. Delmar, Clifton Park, NY.

[27] Hill P.L., Roberts B.W., Grogger J.T., Guryan J. and Sixkiller K. (2011) Decreasing Delinquency, Criminal Behavior, and Recidivism by Intervening on Psychological Factors Other Than Cognitive Ability: A Review of the Intervention Literature. In Cook P.J., Ludwig J. and Mccrary J. (Eds.) Controlling Crime: Strategies and Tradeoffs. University of Chicago Press.

[28] Jacob B.A. and Lefgren L. (2003) Are Idle Hands the Devil's Workshop? Incapacitation, Concentration, and Juvenile Crime. American Economic Review, 93: 5, 15601577

[29] Juvenile Punishment Handbook (2005) Ohjenuora: Nuorisorangaistuksen sisältökäsikirja. Rikosseuraamuslaitoksen Käsikirjoja 2/2005, Helsinki.

[30] Kainulainen S. and Rautio M. (2003) Velkaantuminen yhteiskuntaan integroitumisen esteenä: Tutkimus vankilasta vapautuvien ja yhdyskuntaseuraamusta suorittavien velkatilanteesta. Kriminaalihuollon Tukisäätiö, Helsinki.

[31] Kaplow L. and Shavell S. (2002) On the Superiority of Corrective Taxes to Quantity Regulation. American Law and Economics Review, 4: 1, 1 
[32] Kaplow L. and Shavell S. (2002) Fairness Versus Welfare. Journal of Economics, 80: $2,171-173$.

[33] Kaufman J.G. and Widom C.S. (1999) Childhood Victimization, Running Away, and Delinquency, Journal of Research in Crime and Delinquency, 36: 4, 347

[34] Keisala H. and Marttunen M. (2007) Nuorisorangaistus: Nuorisoprosessi ja Tuomitseminen. Oikeuspoliittinen Tutkimuslaitos, Helsinki.

[35] Kessler D. and Levitt S. (1999) Using Sentence Enhancements to Distinguish between Deterrence and Incapacitation. Journal of Law \& Economics, 42: 1, 343-63.

[36] Kling J.R.. (2006) Incarceration Length, Employment, and Earnings. American Economic Review: Vol. 96 No. 3 (June 2006)

[37] Landenberger and Lipsey (2005) The Positive Effect of Cognitive-Behavioral Programs for Offenders: A Meta-analysis of Factors Associated with Effective Treatment. Journal of Experimental Criminology 1: 4, 451-476.

[38] Landerso R. (2012) Does Incarceration Length Affect Labor Market Outcomes for Violent Offenders? The Rockwool Foundation Research Unit. Study Paper No. 39

[39] Lee D.S. and Mccrary J. (2009) The Deterrence Effect of Prison: Dynamic Theory and Evidence. Mimeo (see also NBER Working Paper 11491).

[40] Levitt S.D. (1996) The Effect of Prison Population Size on Crime Rates: Evidence from Prison Overcrowding Litigation. Quarterly Journal of Economics, 111: 2, 319-51

[41] Levitt S.D. (1997) Using Electoral Cycles in Police Hiring to Estimate the Effect of Police on Crime. American Economic Review, 87: 3, 270-90

[42] Levitt S.D. (1998) Juvenile Crime and Punishment. Journal of Political Economy, 106: 6, 1156-1185 
[43] Lipsey M.W. (2009) The Primary Factors That Characterize Effective Interventions with Juvenile Offenders: A meta-Analytic Overview. Victims and Offenders, 4: 2, 124-147.

[44] Lipsey M. W. and Wilson D. B. (1998) Serious and Violent Juvenile Offenders: Risk Factors and Successful Intervention. In Loeber R. and Farrington D.P. (Eds.) Effective Intervention for Serious Juvenile Offenders: A Synthesis of Research. Thousand Oaks, California

[45] Lipsey M.W., Wilson D.B. and Cothern L. (2000) Effective Intervention for Serious Juvenile Offenders. Juvenile Justice Bulletin, April 2000. US Department of Justice.

[46] Lochner L. and Moretti E. (2004) The Effect of Education on Crime: Evidence from Prison Inmates, Arrests, and Self-Reports. American Economic Review, 94: 1, 155189

[47] Ludwig J., Duncan G.J. and Hirschfield P. (2001) Urban Poverty and Juvenile Crime: Evidence From a Randomized Housing-Mobility Experiment. Quarterly Journal of Economics, 116: 2, 655-679

[48] Lyman D.R., Milich R., Zimmerman R., Novak S.P., Logan T.K., Martin C., Leukefeld C. and Clayton R. (1999) Project DARE: No Effects at Ten-year Follow-up. Journal of Consulting and Clinical Psychology, 67: 4, 590-593.

[49] Machin S., Marie O. and Vujic S. (2011) The Crime Reducing Eeffect of Education. Economic Journal, forthcoming.

[50] Mackillop J., Lisman S.A., Weinstein A. and Rosenbaum D. (2003) Controversial Treatment for Alcoholism. In Lilienfeld S., Lynn S.J. and Lohr J.M. (Eds.) Science and Pseudoscience in Clinical Psychology. Guildford Press, New York.

[51] Marttunen M. (2004) Ehdollisen vankeusrangaistuksen oheisseuraamusten käyttö. Haaste, 4, 25-26 
[52] Marttunen M. and Takala J-P. (2002): Nuorisorangaistus 1997-2001. Uuden rangaistuslajin arviointia. OPTL:n julkaisuja 193. Helsinki.

[53] Mcconnaughy E.A., Prochaska J.O. and Velicer W.F. (1983) Stages of Change in Psychotherapy: Measurement and Sample Profiles. Psychotherapy: Theory, Research and Practice, 20: 3, 368

[54] McGuire, James. (1995). What Works: Reducing Re-offending: Guidelines from Research and Practice. Chichester: John Wiley \& Sons.

[55] Miller and Rollnick (1991) Motivational Interviewing. Preparing People to Change Addictive Behavior. Guildford, New York.

[56] Miller W.R. and Tonigan J.S. (1996). Assessing drinkers' motivation for change: The Stages of Change Readiness and Treatment Scale (SOCRATES), Psychology of Addictive Behaviors, 10, 81-89

[57] Millstein S.G. and Halpern-Felsher B.L. (2002a) Judgments About Risk and Perceived Invulnerability in Adolescents and Young Adults. Journal of Research on Adolescence, 12: $4,399-422$

[58] Millstein S.G. and Halpern-Felsher B.L. (2002b) Perceptions of Risk and Velnerability. The Journal of Adolescent Health, 31: 1, 10-27

[59] Mitchell O., Wilson D.B. and MacKenzie D.L. (2007) Does Incarceration-based Drug Treatment Reduce Recidivism? A Meta-analytic Synthesis of Research. Journal of Experimental Criminology, 3: 4, 353-375.

[60] Novaco R.W. (1975) Anger Control. Lexington Books, Lexington, MA.

[61] Polinsky A.M. and Shavell S. (2006) Public Enforcement of Law. In Polinsky A.M. and Shavell S. (Eds.) The Handbook of Law and Economics. North Holland/Elsevier, Amsterdam.

[62] Quadrel M.J., Fishhoff B. and Davis W. (1993) Adolescent (In)vulnerability. American Psychologist, 48: 2, 102-116. 
[63] Rikollisuustilanne (2009) Rikollisuus- ja seuraamusjärjestelmä tilastojen valossa. Oikeupoliittisen Tutkimuslaitoksen Tutkimuksia 250, Helsinki.

[64] Shavell S. (1987) A Model of Optimal Incapacitation. American Economic Review, 77: $2,107-10$.

[65] Siegel J.M. (1986) The Multidimensional Anger Inventory. Journal of Personality and Social Psychology, 51: 1

[66] Tarolla S.M., Wagner E.F., Rabinowitz J. and Tubman J.G. (2002) Understanding and Treating Juvenile Offenders: A Review of Current Knowledge and Future Directions. Aggression and Violent Behavior, 7, 125-143.

[67] Vankien Terveydenhuollon Kehittäminen (2003) Työryhmän Raportti. Rikosseuraamusviraston monisteita $1 / 2003$.

[68] Waldfogel J. (1994) The Effect of Criminal Convictions on Income and the Trust "Reposed in the Workmen", Journal of Human Resources 29: 62-81

[69] Werch C.E. and Owen D.M (2002) Iatrogenic Effects of Alcohol and Drug Prevention Programs. Journal of Studies on Alcohol, 63: 5, 581-590

[70] Western B., Kling J.R. and Weiman D.F. (2001) The Labor Market Consequences of Incarceration. Crime $\&$ Delinquency, 47: 3, 410-427

[71] Wilson D.B., Gallgher C.A. and MacKenzie D.L. (2000) A Meta-analysis of Corrections-based Education, Vocation Work Programs for Adult Offenders. Journal of Research in Crime and Delinquency, 37: 4, 347-368.

[72] Wilson D.B. (2009) Lessons Learned about Reducing Recidivism from Research on Correctional and Juvenile Delinquency Programs, Briefings, George Mason University. 
Tables and Figures

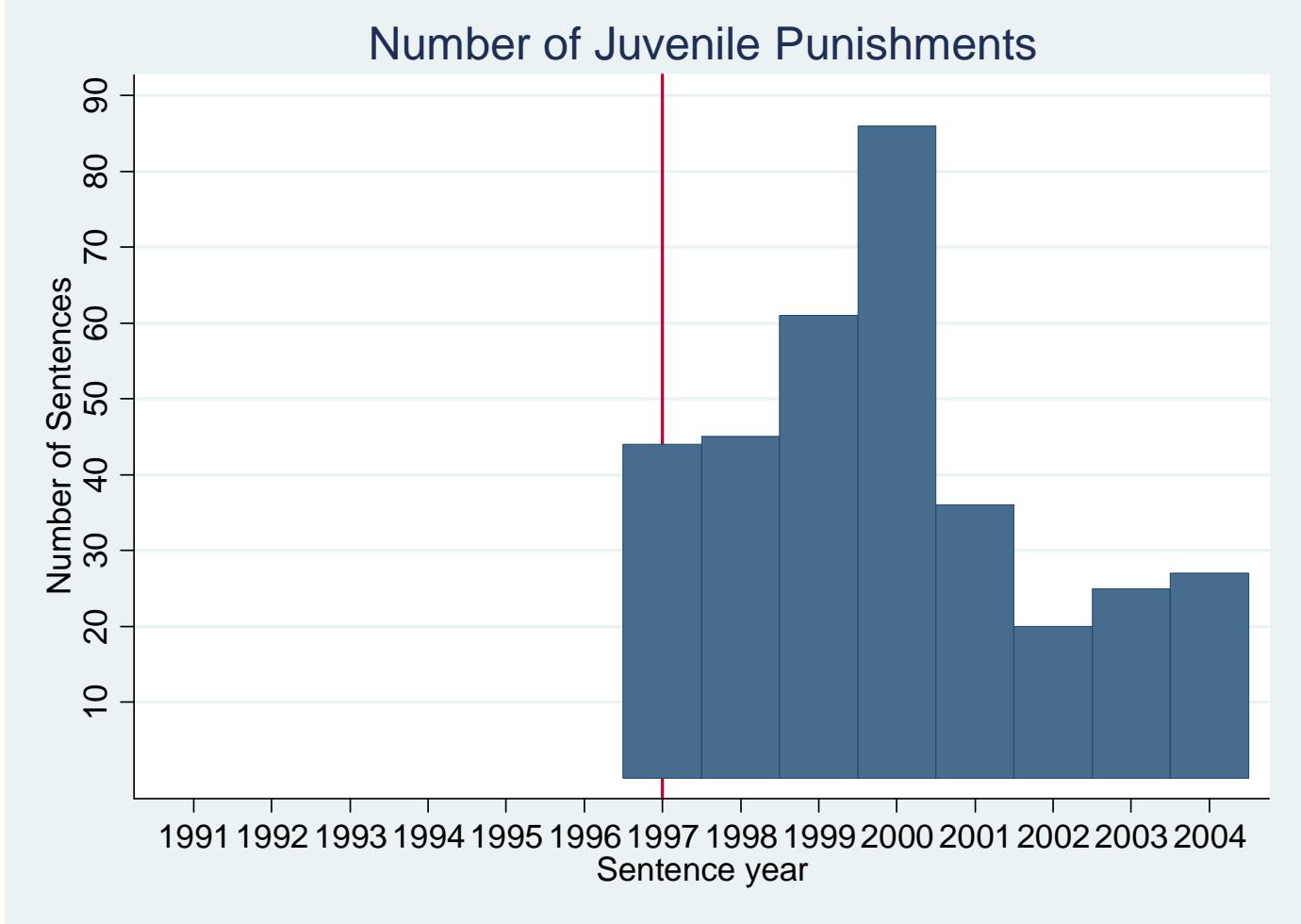

Figure 1: Number of juvenile punishments by year 


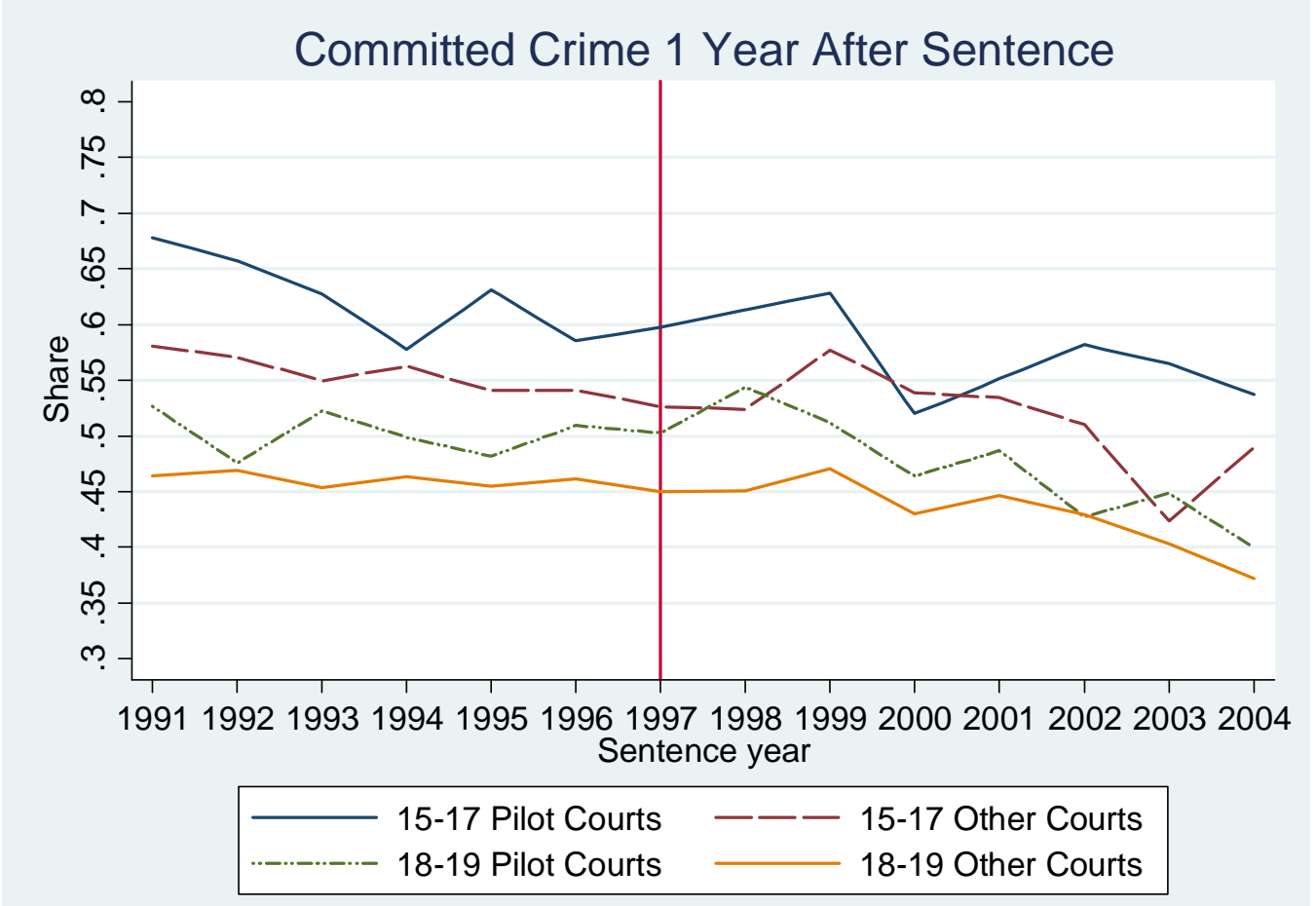

*Notes: Data consist of 15-19-year old males sentenced to prison, probation or community service in 1991-2004.

Figure 2: Share of offenders that committed a new crime within one year after the sentence

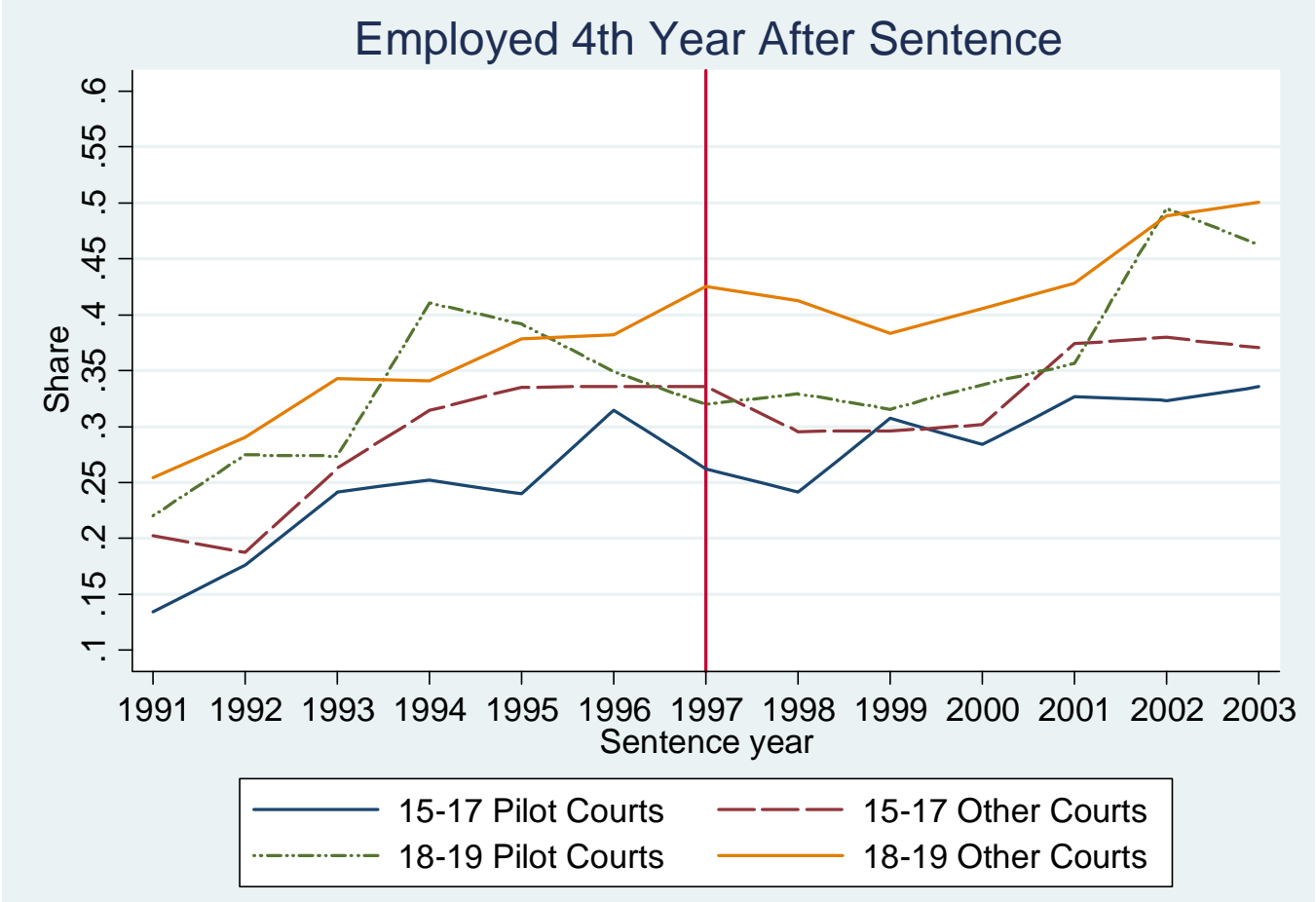

*Notes: Data consist of 15-19-year old males sentenced to prison, probation or community service in 1991-2004.

Figure 3: Share of offenders that were employed in the fourth year after sentence 

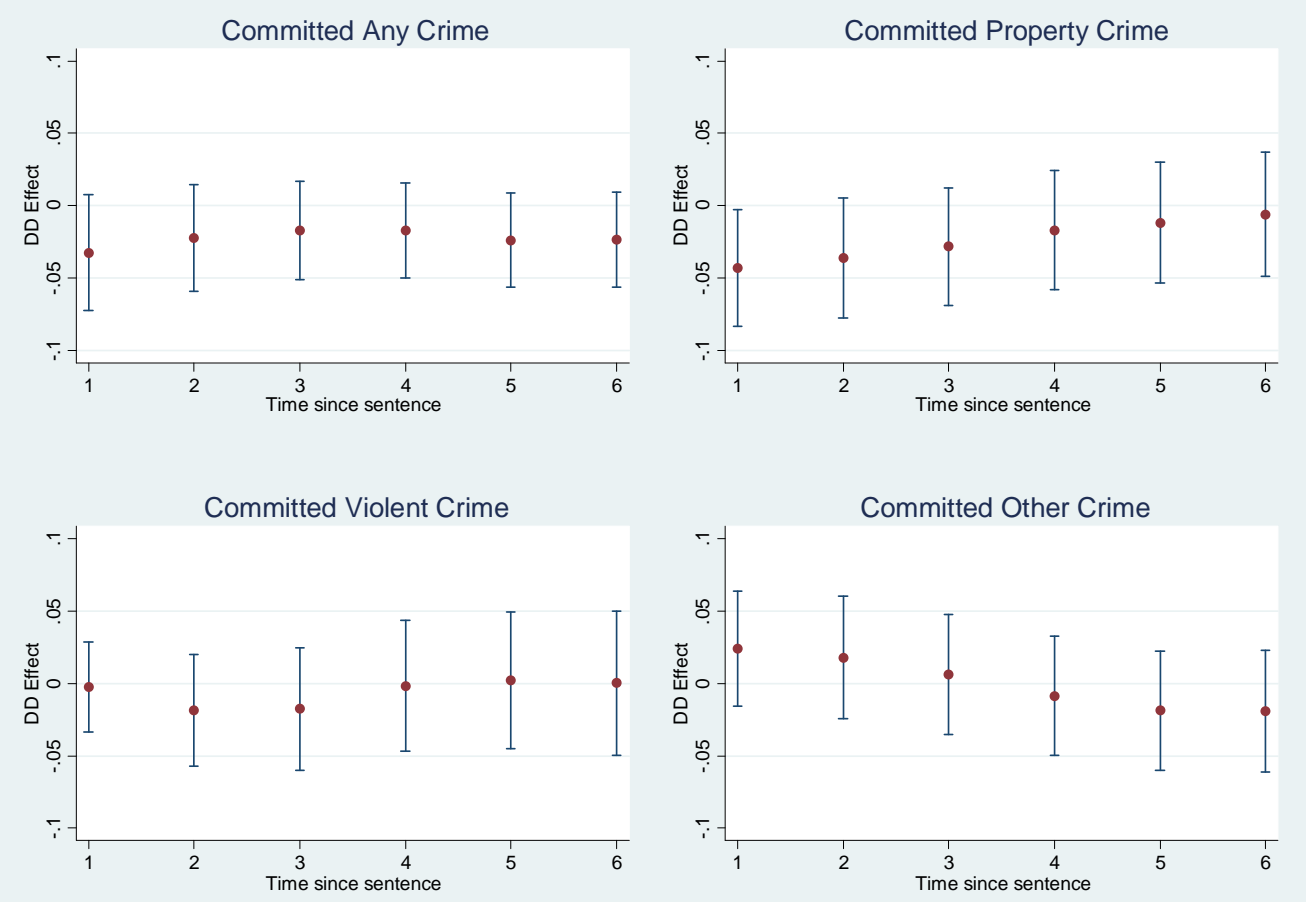

*Notes: The dependent variable is: committed (any, property, violent or other) crime by the year since sentence. Other crimes include “crime against law or order”, traffic crimes, and alcohol and drug related crimes. Sample consists of young (aged 15-17 at the time of crime) male offenders sentenced to prison, probation or juvenile punishment sentences for all crimes (except sex crimes) in 1991-2004. The figure plots the coefficient pilot*after in the differencesdifferences specification that is estimated separately for each post sentence time period, and the 95\% confidence intervals around it. Pilot describes the court locations in which the juvenile punishment took effect after 1997. Standards errors are clustered at the individual level.

Figure 4: Difference-in-differences estimates for the effect of juvenile punishment on cumulative crime outcomes by year since sentence 

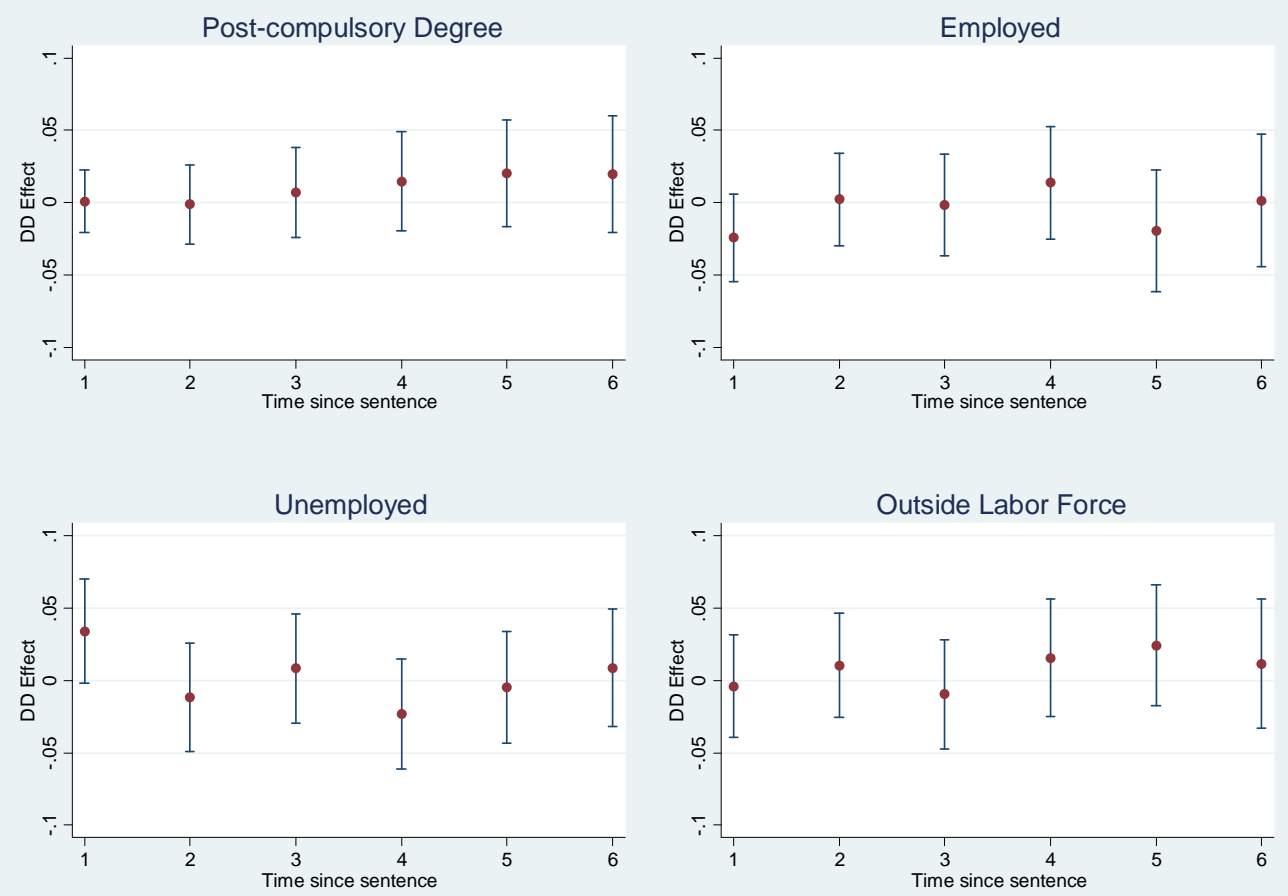

* Notes: Sample consists of young (aged 15-17 at the time of crime) male offenders sentenced to prison, probation or juvenile punishment sentences for all crimes (except sex crimes) in 1991-2004. The figure plots the coefficient pilot*after in the differences-differences specification that is estimated separately for each post sentence time period, and the 95\% confidence intervals around it. Pilot describes the court locations in which the juvenile punishment took effect after 1997. Standards errors are clustered at the individual level.

Figure 5: Difference-in-differences estimates for the effect of juvenile punishment on labor market outcomes by year since sentence 

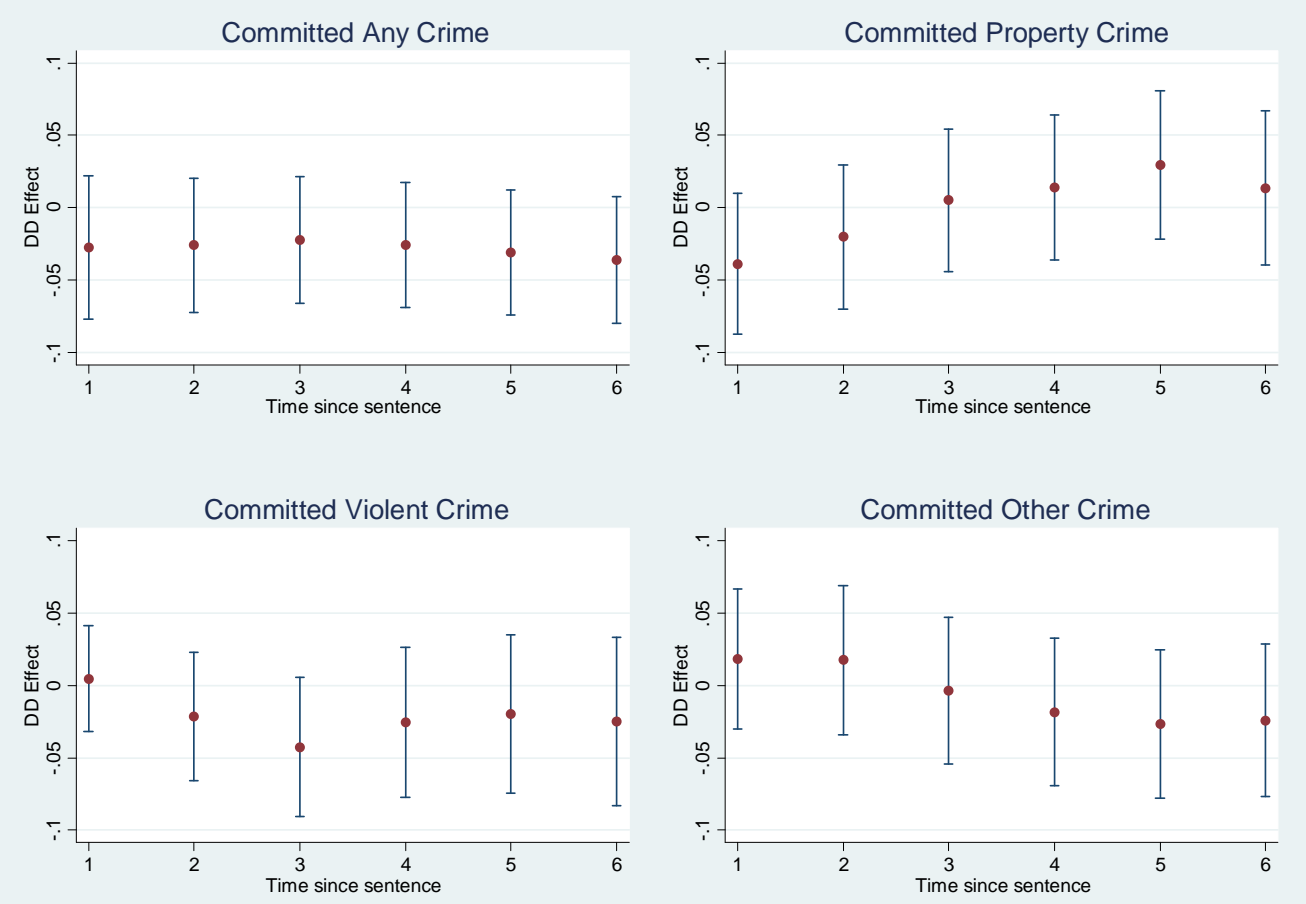

*Notes: The dependent variable is: committed (any, property, violent or other) crime by the year since sentence. Other crimes include “crime against law or order”, traffic crimes, and alcohol and drug related crimes. Sample consists of young (aged 15-19 at the time of crime) male offenders sentenced to prison, probation or juvenile punishment sentences for all crimes (except sex crimes) in 1991-2004. The figure plots the coefficient pilot*young*after in the triple differences specification that is estimated separately for each post sentence time period, and the 95\% confidence intervals around it. Pilot describes the court locations in which the juvenile punishment took effect after 1997. Standards errors are clustered at the individual level.

Figure 6: Triple differences estimates for the effect of juvenile punishment on cumulative crime outcomes by year since sentence 

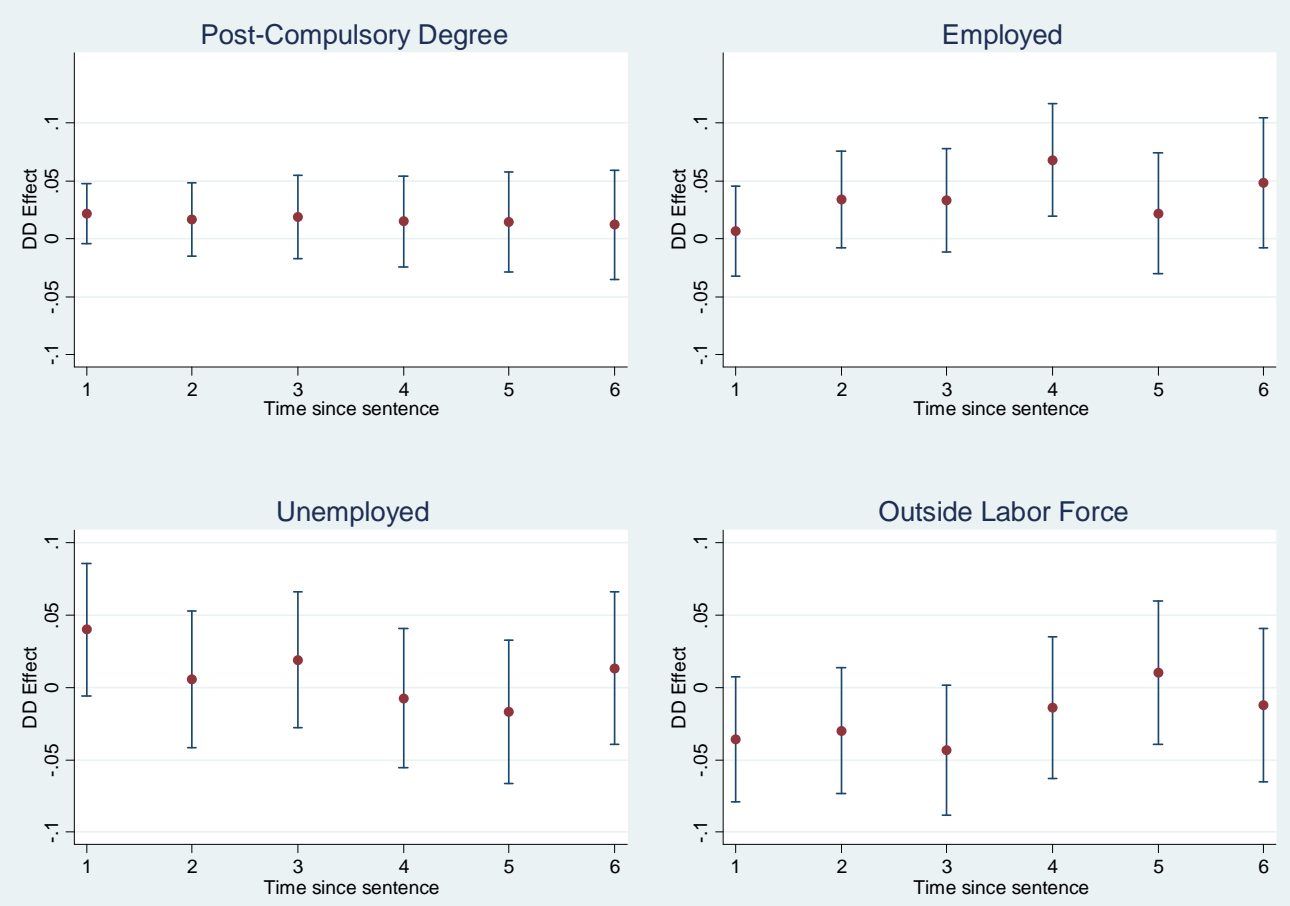

*Notes: Sample consists of young (aged 15-19 at the time of crime) offenders sentenced to prison, probation or juvenile punishment sentences for all crimes (except sex crimes) in 1991-2004. The figure plots the coefficient pilot*young*after in the triple differences specification that is estimated separately for each post sentence time period, and the 95\% confidence intervals around it. Pilot describes the court locations in which the juvenile punishment took effect after 1997. Standards errors are clustered at the individual level.

Figure 7: Triple differences estimates for the effect of juvenile punishment on labor market outcomes by year since sentence 


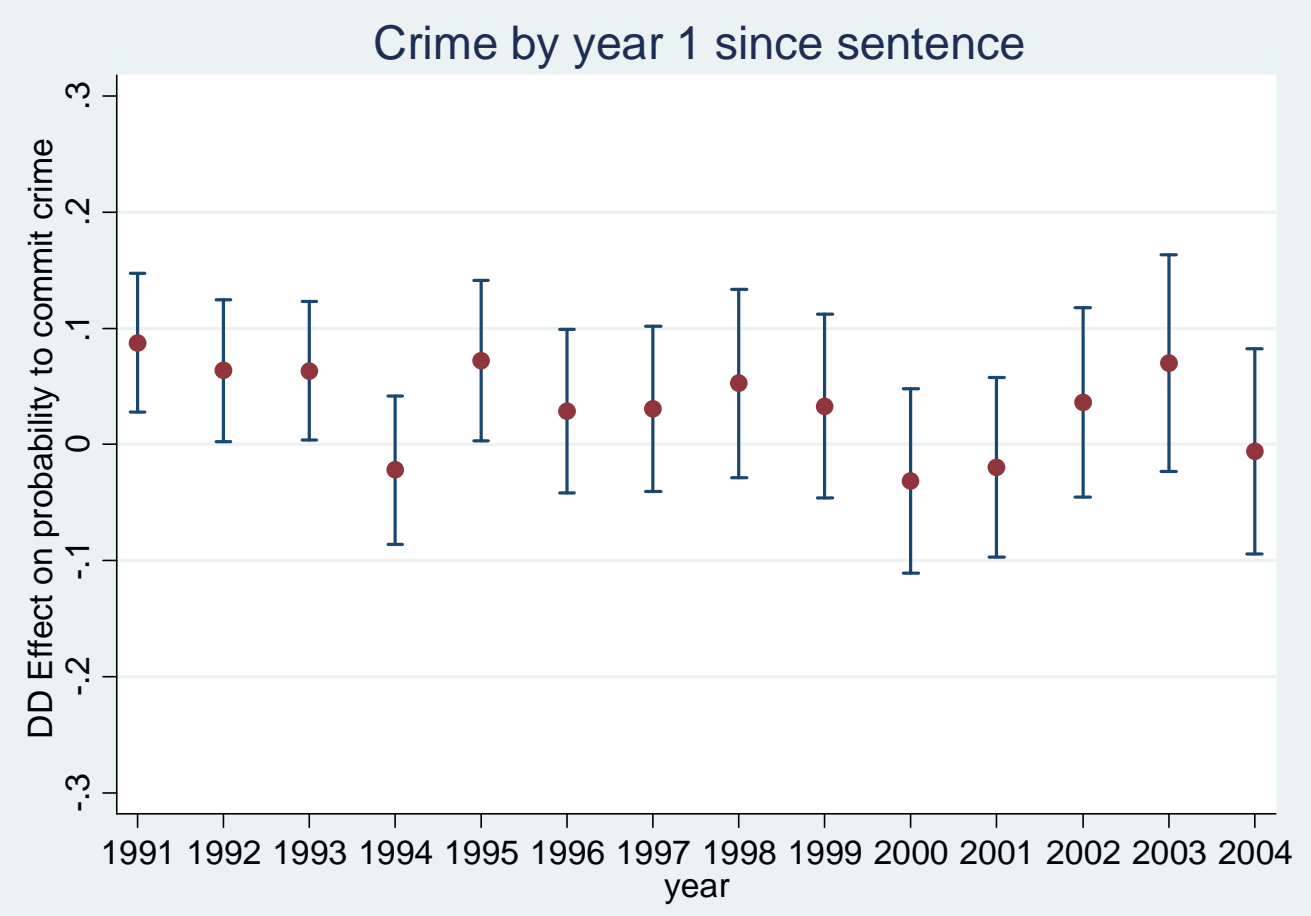

*Notes: Figure plots the pilot *year interaction in a model that estimates the effect on the reoffending probability using data for 15-17 year old offenders. See notes under figure 4.

Figure 8: The difference-in-differences estimate on the effect of eligibility on crime within one year after sentence by year

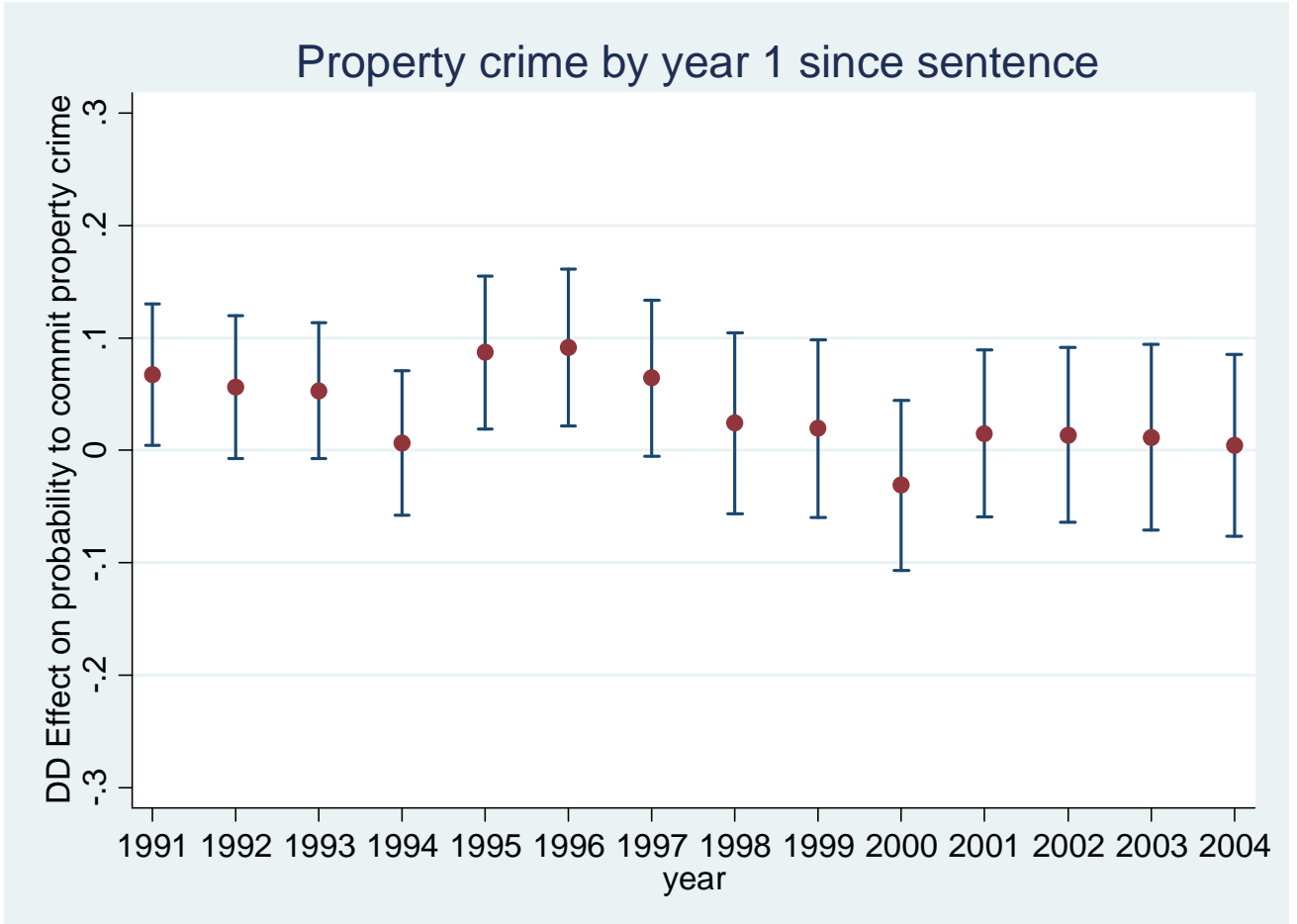

*Notes: Figure plots the pilot *year interaction in a model that estimates the effect on the reoffending probability using data for 15-17 year old offenders. See notes under figure 4.

Figure 9: The difference-in-differences estimate on the effect of eligibility on property crime within one year after sentence by year 
Table 1: Distribution of punishments and crimes

\begin{tabular}{|c|c|c|c|c|c|c|}
\hline Crime/Sentence & Prison & $\begin{array}{l}\text { Community } \\
\text { Sentence }\end{array}$ & Probation & $\begin{array}{l}\text { Probation } \\
\text { with fine }\end{array}$ & $\begin{array}{l}\text { Juvenile } \\
\text { Punishments }\end{array}$ & Total \\
\hline Property Crime & 4,382 & 1,254 & 847 & 13,243 & 201 & 19,927 \\
\hline Violent Crime & 745 & 475 & 470 & 4,193 & 102 & 5,985 \\
\hline Crime Against & 198 & 59 & 66 & 613 & 9 & 945 \\
\hline Law or Order & & & & & & \\
\hline Traffic crimes & 1,330 & 894 & 6,622 & 3,143 & 56 & 12,045 \\
\hline $\begin{array}{l}\text { Drug, alcohol and } \\
\text { other crimes }\end{array}$ & 859 & 233 & 210 & 2,620 & 36 & 3,958 \\
\hline Total & 7,514 & 2,915 & 8,215 & 23,812 & 404 & 42,860 \\
\hline
\end{tabular}

*Notes: Data consist of all primary sentences committed by 15-19 year old male offenders in years 1991-2004. Fines and no sentences, and sentences for sex crimes are excluded. 
Table 2: Descriptive evidence of offenders by age-at-crime and location of sentencing court

\begin{tabular}{|c|c|c|c|c|c|c|c|c|c|}
\hline & \multirow{2}{*}{$\begin{array}{l}\text { Juvenile } \\
\text { after }\end{array}$} & \multicolumn{2}{|c|}{ 15-17 pilot } & \multicolumn{2}{|c|}{ 15-17 non-pilot } & \multicolumn{2}{|c|}{ 18-19 pilot } & \multicolumn{2}{|c|}{ 18-19 non-pilot } \\
\hline & & before & after & before & after & before & after & before & after \\
\hline Finnish Speaker & .99 & 0.98 & 0.95 & 1.00 & 0.99 & 0.99 & 0.95 & 1.00 & 0.99 \\
\hline More than Compulsory Schooling* & 0.01 & 0.02 & 0.01 & 0.04 & 0.03 & 0.09 & 0.15 & 0.15 & 0.21 \\
\hline Employed & 0.10 & 0.09 & 0.12 & 0.09 & 0.12 & 0.12 & 0.19 & 0.12 & 0.21 \\
\hline Student* & 0.36 & 0.28 & 0.36 & 0.31 & 0.46 & 0.11 & 0.18 & 0.13 & 0.22 \\
\hline Earnings & 811.55 & 947.29 & 1017.98 & 1052.55 & 1064.65 & 1948.96 & 2364.478 & 2024.31 & 2520.78 \\
\hline $\begin{array}{l}\text { Mother Only Compulsory } \\
\text { Schooling* }\end{array}$ & 0.44 & 0.33 & 0.43 & 0.42 & 0.56 & 0.32 & 0.51 & 0.41 & 0.61 \\
\hline $\begin{array}{l}\text { Father Only Compulsory } \\
\text { Schooling* }\end{array}$ & 0.42 & 0.33 & 0.39 & 0.33 & 0.46 & 0.31 & 0.46 & 0.32 & 0.49 \\
\hline Father’s earnings & 9058.37 & 9846.35 & 10244.75 & 10494.46 & 11497.2 & 10923.96 & 12545.99 & 9990.95 & 12584.75 \\
\hline Mother's earnings & 9328.55 & 10677.19 & 9833.82 & 9524.89 & 10510.73 & 10938.94 & 12007.94 & 9743.03 & 11549.37 \\
\hline Sibling & 0.88 & 0.84 & 0.88 & 0.86 & 0.90 & 0.80 & 0.85 & 0.85 & 0.88 \\
\hline Househol with children & 0.66 & 0.66 & 0.65 & 0.70 & 0.67 & 0.48 & 0.45 & 0.53 & 0.46 \\
\hline Father's income & 17166.98 & 16031.48 & 18717.39 & 16480.53 & 20001.51 & 177533.57 & 21907.45 & 16750.77 & 21816.69 \\
\hline Mother's income & 14132.64 & 13701.2 & 14692.01 & 12700.74 & 15364.7 & 14291.68 & 17175.48 & 13037.6 & 16728.92 \\
\hline Lives w. Mother & 0.60 & 0.57 & 0.57 & 0.61 & 0.57 & 0.40 & 0.37 & 0.44 & 0.37 \\
\hline Lives w. Father & 0.20 & 0.29 & 0.25 & 0.33 & 0.33 & 0.24 & 0.22 & 0.31 & 0.26 \\
\hline Father dead & 0.09 & 0.07 & 0.08 & 0.08 & 0.09 & 0.08 & 0.09 & 0.09 & 0.10 \\
\hline Mother dead & 0.02 & 0.03 & 0.02 & 0.02 & 0.02 & 0.04 & 0.03 & 0.03 & 0.03 \\
\hline Sentenced t-1 & 0.67 & 0.65 & 0.58 & 0.61 & 0.47 & 0.64 & 0.58 & 0.61 & 0.51 \\
\hline $\begin{array}{l}\text { Parent sentenced to prison or } \\
\text { probation* }\end{array}$ & 0.53 & 0.39 & 0.49 & 0.38 & 0.44 & 0.35 & 0.41 & 0.33 & 0.39 \\
\hline Crimes Solved in Region > 70\% & 0.13 & 0.28 & 0.16 & 0.48 & 0.52 & 0.28 & 0.19 & 0.54 & 0.55 \\
\hline Property & 0.50 & 0.68 & 0.51 & 0.65 & 0.46 & 0.52 & 0.41 & 0.46 & 0.32 \\
\hline Violent & 0.25 & 0.12 & 0.24 & 0.10 & 0.22 & 0.09 & 0.15 & 0.09 & 0.15 \\
\hline Traffic & 0.14 & 0.12 & 0.15 & 0.16 & 0.24 & 0.24 & 0.30 & 0.31 & 0.41 \\
\hline Agains police & 0.02 & 0.02 & 0.02 & 0.03 & 0.02 & 0.03 & 0.01 & 0.03 & 0.02 \\
\hline Alcohol or drug related & 0.09 & 0.06 & 0.09 & 0.05 & 0.06 & 0.13 & 0.13 & 0.10 & 0.10 \\
\hline Observations & 404 & 3010 & 2858 & 5506 & 4962 & 3072 & 4830 & 7343 & 11279 \\
\hline
\end{tabular}

*Notes: Data consist of all primary sentences committed by 15-19 year old male offenders in years 1991-2004. Fines and no sentences, and sentences for sex crimes are excluded. *Including drug and alcohol related crimes. 
Table 3: Difference-in-Differences Estimates for the Effect of Juvenile Punishment on Crime and Labor Market Outcomes

\begin{tabular}{|c|c|c|c|c|c|c|}
\hline \multirow[b]{2}{*}{ Outcome variable } & \multicolumn{6}{|c|}{ Follow up period } \\
\hline & Year 1 & Year 2 & Year 3 & Year 4 & Year 5 & Year 6 \\
\hline \multicolumn{7}{|l|}{ Crime related outcomes } \\
\hline Any crime & $\begin{array}{l}-0.032 \\
(0.020)\end{array}$ & $\begin{array}{l}-0.022 \\
(0.019)\end{array}$ & $\begin{array}{l}-0.017 \\
(0.017)\end{array}$ & $\begin{array}{l}-0.017 \\
(0.017)\end{array}$ & $\begin{array}{l}-0.024 \\
(0.017)\end{array}$ & $\begin{array}{l}-0.023 \\
(0.017)\end{array}$ \\
\hline Property crime & $\begin{array}{l}-0.043 * * \\
(0.021)\end{array}$ & $\begin{array}{l}-0.036^{*} \\
(0.021)\end{array}$ & $\begin{array}{l}-0.028 \\
(0.021)\end{array}$ & $\begin{array}{l}-0.017 \\
(0.021)\end{array}$ & $\begin{array}{l}-0.012 \\
(0.021)\end{array}$ & $\begin{array}{l}-0.006 \\
(0.022)\end{array}$ \\
\hline Violent crime & $\begin{array}{l}-0.003 \\
(0.016)\end{array}$ & $\begin{array}{l}-0.019 \\
(0.020)\end{array}$ & $\begin{array}{l}-0.018 \\
(0.021)\end{array}$ & $\begin{array}{l}-0.002 \\
(0.023)\end{array}$ & $\begin{array}{l}0.002 \\
(0.024)\end{array}$ & $\begin{array}{l}0.000 \\
(0.025)\end{array}$ \\
\hline Other crime & $\begin{array}{l}0.024 \\
(0.020)\end{array}$ & $\begin{array}{l}0.018 \\
(0.022)\end{array}$ & $\begin{array}{l}0.006 \\
(0.021)\end{array}$ & $\begin{array}{l}-0.009 \\
(0.021)\end{array}$ & $\begin{array}{l}-0.019 \\
(0.021)\end{array}$ & $\begin{array}{l}-0.019 \\
(0.021)\end{array}$ \\
\hline Observations & 10,450 & 10,450 & 10,450 & 9,942 & 9,427 & 8,829 \\
\hline Schooling outcomes & & & & & & \\
\hline $\begin{array}{l}\text { Obtained post- } \\
\text { compulsory degree } \\
\text { Employment Outcomes }\end{array}$ & $\begin{array}{l}0.001 \\
(0.011)\end{array}$ & $\begin{array}{l}-0.001 \\
(0.014)\end{array}$ & $\begin{array}{l}0.007 \\
(0.016)\end{array}$ & $\begin{array}{l}0.015 \\
(0.017)\end{array}$ & $\begin{array}{l}0.020 \\
(0.019)\end{array}$ & $\begin{array}{l}0.020 \\
(0.021)\end{array}$ \\
\hline Employed & $\begin{array}{l}-0.024 \\
(0.015)\end{array}$ & $\begin{array}{l}0.002 \\
(0.016)\end{array}$ & $\begin{array}{l}-0.001 \\
(0.018)\end{array}$ & $\begin{array}{l}0.014 \\
(0.020)\end{array}$ & $\begin{array}{l}-0.019 \\
(0.021)\end{array}$ & $\begin{array}{l}0.001 \\
(0.023)\end{array}$ \\
\hline Unemployed & $\begin{array}{l}0.034^{*} \\
(0.018)\end{array}$ & $\begin{array}{l}-0.012 \\
(0.019)\end{array}$ & $\begin{array}{l}0.008 \\
(0.019)\end{array}$ & $\begin{array}{l}-0.023 \\
(0.019)\end{array}$ & $\begin{array}{l}-0.005 \\
(0.020)\end{array}$ & $\begin{array}{l}0.009 \\
(0.021)\end{array}$ \\
\hline Not participating & $\begin{array}{l}-0.004 \\
(0.018)\end{array}$ & $\begin{array}{l}0.010 \\
(0.018)\end{array}$ & $\begin{array}{l}-0.010 \\
(0.019)\end{array}$ & $\begin{array}{l}0.015 \\
(0.021)\end{array}$ & $\begin{array}{l}0.024 \\
(0.021)\end{array}$ & $\begin{array}{l}0.011 \\
(0.023)\end{array}$ \\
\hline Income & $\begin{array}{l}-218.242 \\
(181.651)\end{array}$ & $\begin{array}{l}-28.702 \\
(208.390)\end{array}$ & $\begin{array}{l}-185.023 \\
(272.470)\end{array}$ & $\begin{array}{l}-153.133 \\
(338.639)\end{array}$ & $\begin{array}{l}-129.042 \\
(404.067)\end{array}$ & $\begin{array}{l}-587.157 \\
(452.438)\end{array}$ \\
\hline Observations & 10,372 & 10,306 & 10,211 & 9,628 & 9,064 & 8,423 \\
\hline
\end{tabular}


Table 4: Triple Differences Estimates for the Effect of Juvenile Punishment on Crime and Labor Market Outcomes

\begin{tabular}{|c|c|c|c|c|c|c|}
\hline \multirow[b]{2}{*}{ Outcome variable } & \multicolumn{6}{|c|}{ Follow up period } \\
\hline & year 1 & Year 2 & Year 3 & Year 4 & Year 5 & Year 6 \\
\hline \multicolumn{7}{|c|}{ Crime related outcomes } \\
\hline Any crime & $\begin{array}{l}-0.027 \\
(0.025)\end{array}$ & $\begin{array}{l}-0.026 \\
(0.024)\end{array}$ & $\begin{array}{l}-0.022 \\
(0.022)\end{array}$ & $\begin{array}{l}-0.026 \\
(0.022)\end{array}$ & $\begin{array}{l}-0.031 \\
(0.022)\end{array}$ & $\begin{array}{l}-0.036 \\
(0.022)\end{array}$ \\
\hline Property crime & $\begin{array}{l}-0.039 \\
(0.025)\end{array}$ & $\begin{array}{l}-0.020 \\
(0.025)\end{array}$ & $\begin{array}{l}0.005 \\
(0.025)\end{array}$ & $\begin{array}{l}0.014 \\
(0.026)\end{array}$ & $\begin{array}{l}0.030 \\
(0.026)\end{array}$ & $\begin{array}{l}0.014 \\
(0.027)\end{array}$ \\
\hline Violent crime & $\begin{array}{l}0.005 \\
(0.019)\end{array}$ & $\begin{array}{l}-0.022 \\
(0.023)\end{array}$ & $\begin{array}{l}-0.043^{*} \\
(0.024)\end{array}$ & $\begin{array}{l}-0.026 \\
(0.026)\end{array}$ & $\begin{array}{l}-0.020 \\
(0.028)\end{array}$ & $\begin{array}{l}-0.025 \\
(0.030)\end{array}$ \\
\hline Other crime & $\begin{array}{l}0.018 \\
(0.025) \\
\end{array}$ & $\begin{array}{l}0.018 \\
(0.026) \\
\end{array}$ & $\begin{array}{l}-0.003 \\
(0.026) \\
\end{array}$ & $\begin{array}{l}-0.019 \\
(0.026) \\
\end{array}$ & $\begin{array}{l}-0.027 \\
(0.026) \\
\end{array}$ & $\begin{array}{l}-0.024 \\
(0.027)\end{array}$ \\
\hline Observations & 28,620 & 28,620 & 28,620 & 26,692 & 24,759 & 22,771 \\
\hline Schooling outcomes & & & & & & \\
\hline $\begin{array}{l}\text { Obtained post- } \\
\text { compulsory degree } \\
\text { Employment Outcomes }\end{array}$ & $\begin{array}{l}0.022 \\
(0.013)\end{array}$ & $\begin{array}{l}0.017 \\
(0.016)\end{array}$ & $\begin{array}{l}0.019 \\
(0.018)\end{array}$ & $\begin{array}{l}0.015 \\
(0.020)\end{array}$ & $\begin{array}{l}0.015 \\
(0.022)\end{array}$ & $\begin{array}{l}0.012 \\
(0.024)\end{array}$ \\
\hline Employed & $\begin{array}{l}0.007 \\
(0.020)\end{array}$ & $\begin{array}{l}0.034 \\
(0.021)\end{array}$ & $\begin{array}{l}0.033 \\
(0.023)\end{array}$ & $\begin{array}{l}0.068 * * * \\
(0.025)\end{array}$ & $\begin{array}{l}0.022 \\
(0.027)\end{array}$ & $\begin{array}{l}0.048^{*} \\
(0.029)\end{array}$ \\
\hline Unemployed & $\begin{array}{l}0.040^{*} \\
(0.023)\end{array}$ & $\begin{array}{l}0.005 \\
(0.024)\end{array}$ & $\begin{array}{l}0.019 \\
(0.024)\end{array}$ & $\begin{array}{l}-0.008 \\
(0.024)\end{array}$ & $\begin{array}{l}-0.017 \\
(0.025)\end{array}$ & $\begin{array}{l}0.013 \\
(0.027)\end{array}$ \\
\hline Not participating & $\begin{array}{l}-0.036 \\
(0.022)\end{array}$ & $\begin{array}{l}-0.030 \\
(0.022)\end{array}$ & $\begin{array}{l}-0.043 * \\
(0.023)\end{array}$ & $\begin{array}{l}-0.014 \\
(0.025)\end{array}$ & $\begin{array}{l}0.010 \\
(0.025)\end{array}$ & $\begin{array}{l}-0.013 \\
(0.027)\end{array}$ \\
\hline Income & $\begin{array}{l}216.352 \\
(235.475)\end{array}$ & $\begin{array}{l}455.665 \\
(291.075)\end{array}$ & $\begin{array}{l}579.446 \\
(357.588)\end{array}$ & $\begin{array}{l}246.059 \\
(419.962)\end{array}$ & $\begin{array}{l}218.508 \\
(511.899)\end{array}$ & $\begin{array}{l}133.886 \\
(576.999)\end{array}$ \\
\hline Observations & 28,379 & 28,155 & 27,942 & 25,829 & 23,758 & 21,648 \\
\hline
\end{tabular}

*Notes: Sample consists of 15-19 year old (at the time of crime) male offenders sentenced to prison, probation or juvenile punishment sentences for all crimes (except sex crimes) in 1991-2004. Other crimes include "crime against law or order", traffic crimes, and alcohol and drug related crimes. The table reports the coefficient pilot*young*after. Pilot describes the court locations in which the juvenile punishment took effect after 1997. Standards errors are clustered at the individual level. 
Table 5: IV Estimates for the effect of juvenile punishment on selected outcomes

\begin{tabular}{lcc}
\hline & DD & DDD \\
\hline Crime $t+1$ & -0.201 & -0.172 \\
& $(0.131)$ & $(0.160)$ \\
Mean & 0.5628 & 0.4945 \\
& $-0.266^{* *}$ & -0.244 \\
Property crime $t+1$ & $(0.132)$ & $(0.157)$ \\
& 0.3989 & 0.3260 \\
Mean & 10,450 & 28,620
\end{tabular}

*Notes: Table reports the 2SLS estimate for the effect of juvenile punishment on crime (or property crime) in year $\mathrm{t}+1$. The juvenile punishment is instrumented with eligibility (after*pilot in DD columns, and after*pilot*young in DDD columns). For other controls see Tables 3 and 4. First stage estimates for each column are C1: 0.1571022 (0.0062611), C2: $0.1585822(0.0047661)$.

Table 6: Difference-in-Differences estimates against alternative comparison groups

\begin{tabular}{|c|c|c|c|c|c|c|}
\hline \multirow[b]{2}{*}{ Outcome variable } & \multicolumn{6}{|c|}{ Follow up period } \\
\hline & Year 1 & Year 2 & Year 3 & Year 4 & Year 5 & Year 6 \\
\hline \multicolumn{7}{|l|}{ Against probation } \\
\hline Any crime & $\begin{array}{l}-0.029 \\
(0.022)\end{array}$ & $\begin{array}{l}-0.017 \\
(0.020)\end{array}$ & $\begin{array}{l}-0.013 \\
(0.019)\end{array}$ & $\begin{array}{l}-0.017 \\
(0.018)\end{array}$ & $\begin{array}{l}-0.024 \\
(0.018)\end{array}$ & $\begin{array}{l}-0.023 \\
(0.018)\end{array}$ \\
\hline Property crime & $\begin{array}{l}-0.039 * \\
(0.021)\end{array}$ & $\begin{array}{l}-0.033 \\
(0.022)\end{array}$ & $\begin{array}{l}-0.025 \\
(0.022)\end{array}$ & $\begin{array}{l}-0.016 \\
(0.022)\end{array}$ & $\begin{array}{l}-0.011 \\
(0.023)\end{array}$ & $\begin{array}{l}-0.003 \\
(0.024)\end{array}$ \\
\hline Observations & 9,453 & 9,453 & 9,453 & 8,986 & 8,505 & 7,957 \\
\hline Against prison & & & & & & \\
\hline Any crime & $\begin{array}{l}-0.078 \\
(0.059)\end{array}$ & $\begin{array}{l}-0.085 * * \\
(0.043)\end{array}$ & $\begin{array}{l}-0.052 \\
(0.035)\end{array}$ & $\begin{array}{l}-0.037 \\
(0.032)\end{array}$ & $\begin{array}{l}-0.025 \\
(0.033)\end{array}$ & $\begin{array}{l}-0.022 \\
(0.031)\end{array}$ \\
\hline Property crime & $\begin{array}{l}-0.103 \\
(0.068) \\
\end{array}$ & $\begin{array}{l}-0.120 * * \\
(0.058)\end{array}$ & $\begin{array}{l}-0.085 \\
(0.052)\end{array}$ & $\begin{array}{l}-0.053 \\
(0.051)\end{array}$ & $\begin{array}{l}-0.036 \\
(0.050)\end{array}$ & $\begin{array}{l}-0.031 \\
(0.048)\end{array}$ \\
\hline Observations & 1,068 & 1,068 & 1,068 & 1,012 & 974 & 930 \\
\hline
\end{tabular}




\section{APPENDIX}
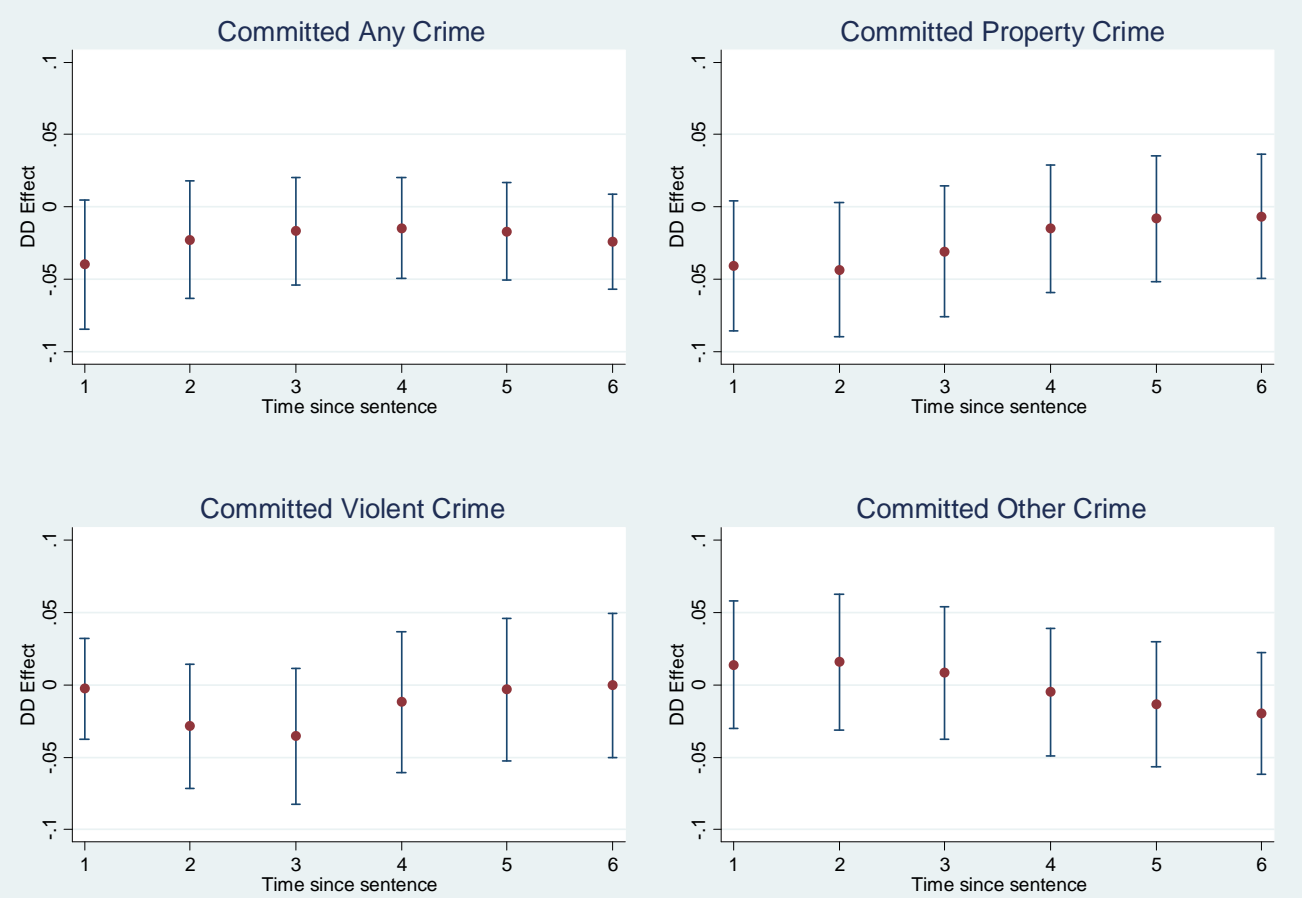

*Notes: The dependent variable is: committed (any, property, violent or other) crime by the year since sentence. Sample consists of young (aged 15-17 at the time of crime) male offenders sentenced to prison, probation or juvenile punishment for all crimes (except sex crimes) in 1991-2001. Each individual can be followed until year 6 after sentence. The figure plots the coefficient pilot*after in the differences-differences specification that is estimated separately for each post sentence time period, and the $95 \%$ confidence intervals around it. Pilot describes the court locations in which the juvenile punishment took effect after 1997. Standards errors are clustered at the individual level.

Figure A1: Difference-in-differences estimates for the effect of juvenile punishment on cumulative crime outcomes by year since sentence: balanced panel 

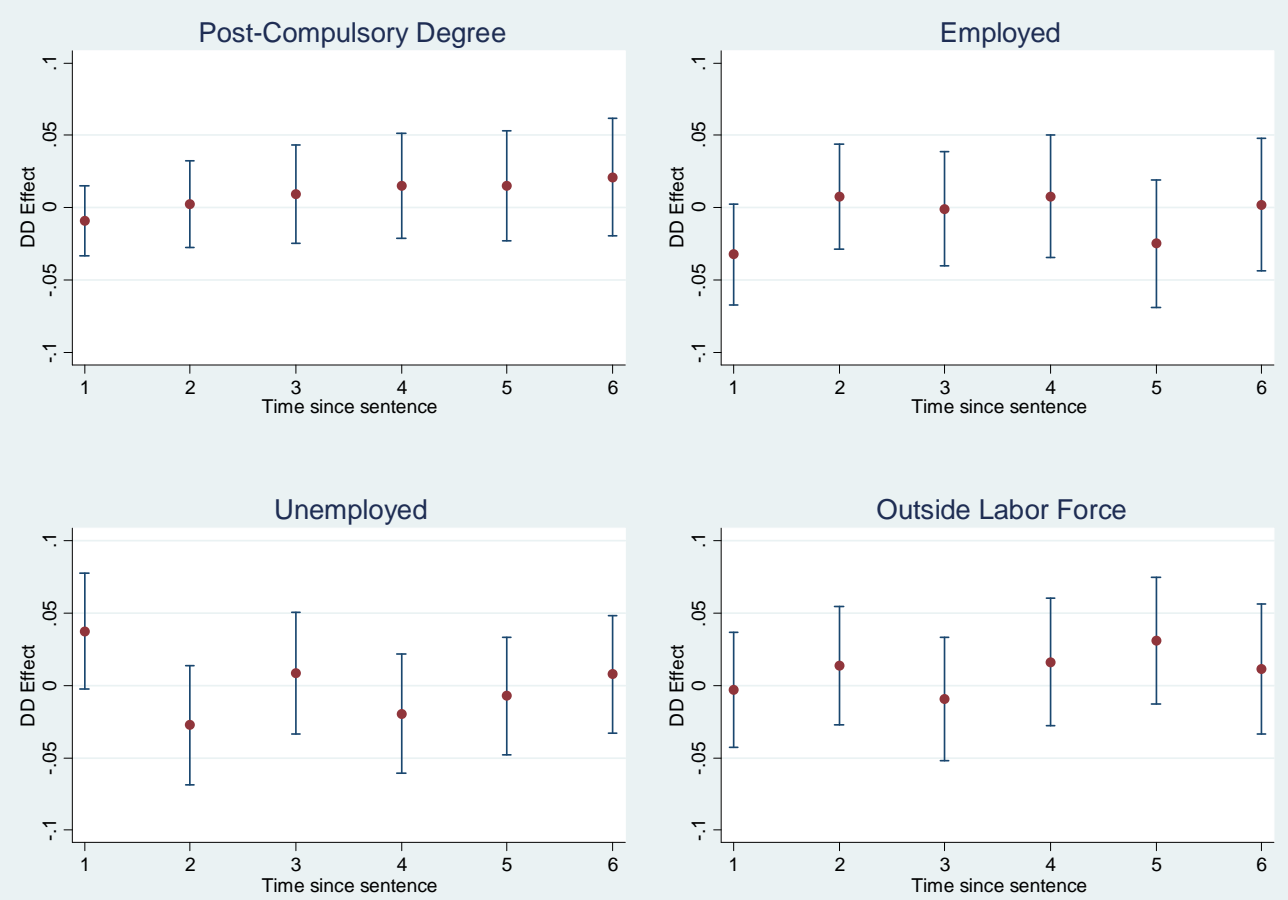

*Notes: The dependent variable is: committed (any, property, violent or other) crime by the year since sentence. Sample consists of young (age 15-17 at the time of crime) male offenders sentenced to prison, probation or juvenile punishment for all crimes (except sex crimes) in 1991-2001. Each individual can be followed until year 6 after sentence. The figure plots the coefficient pilot*after in the differences-differences specification that is estimated separately for each post sentence time period, and the 95\% confidence intervals around it. Pilot describes the court locations in which the juvenile punishment took effect after 1997. Standards errors are clustered at the individual level.

Figure A2: Difference-in-differences estimates for the effect of juvenile punishment labor market outcomes by year since sentence: balanced panel 

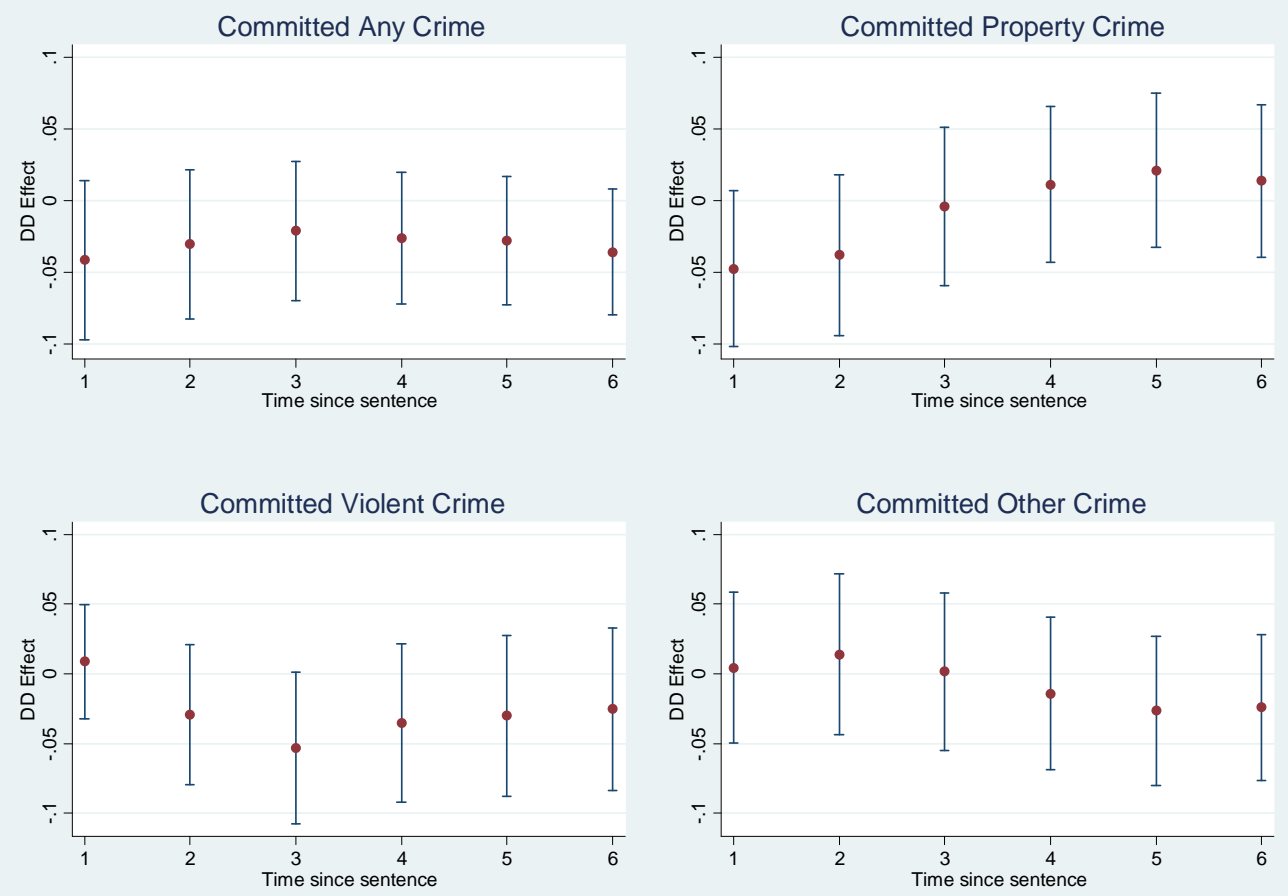

*Notes: The dependent variable is: committed (any, property, violent or other) crime by the year since sentence. Sample consists of young (aged 15-19 at the time of crime) male offenders sentenced to prison, probation or juvenile punishment for all crimes (except sex crimes) in 1991-2001. Each individual can be followed until year 6 after sentence. The figure plots the coefficient pilot*young*after in the triple differences specification that is estimated separately for each post sentence time period, and the 95\% confidence intervals around it. Pilot describes the court locations in which the juvenile punishment took effect after 1997. Standards errors are clustered at the individual level.

Figure A3: Triple differences estimates for the effect of juvenile punishment on cumulative crime outcomes by year since sentence: balanced panel 

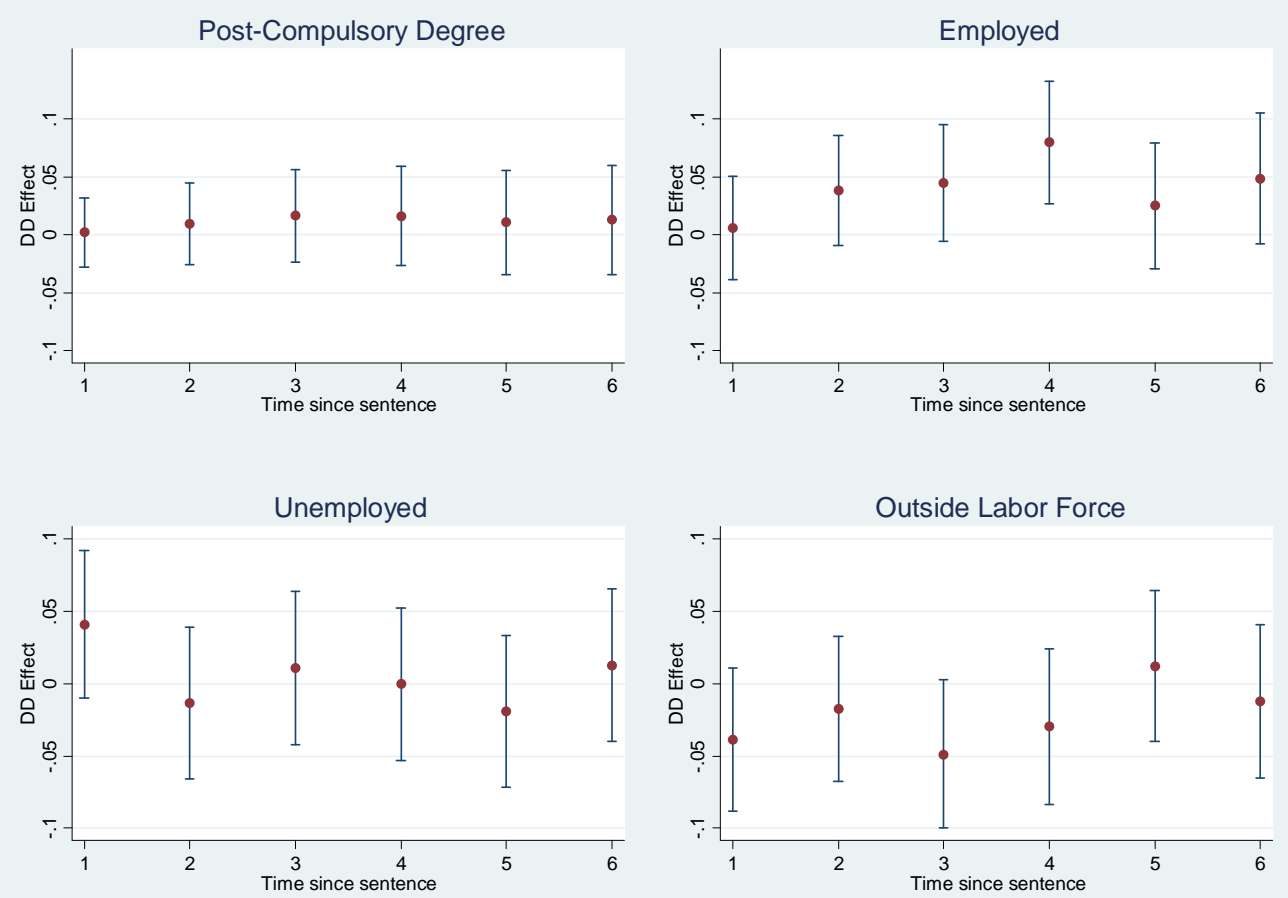

*Notes: The dependent variable is committed (any, property, violent or other) crime by the year since sentence. Sample consists of young (aged 15-19 at the time of crime) male offenders sentenced to prison, probation or juvenile punishment for all crimes (except sex crimes) in 1991-2001. Each individual can be followed until year 6 after sentence. The figure plots the coefficient pilot*young*after in the triple differences specification that is estimated separately for each post sentence time period, and the 95\% confidence intervals around it. Pilot describes the court locations in which the juvenile punishment took effect after 1997. Standards errors are clustered at the individual level.

Figure A4: Triple differences estimates for the effect of juvenile punishment on cumulative crime outcomes by year since sentence: balanced panel 


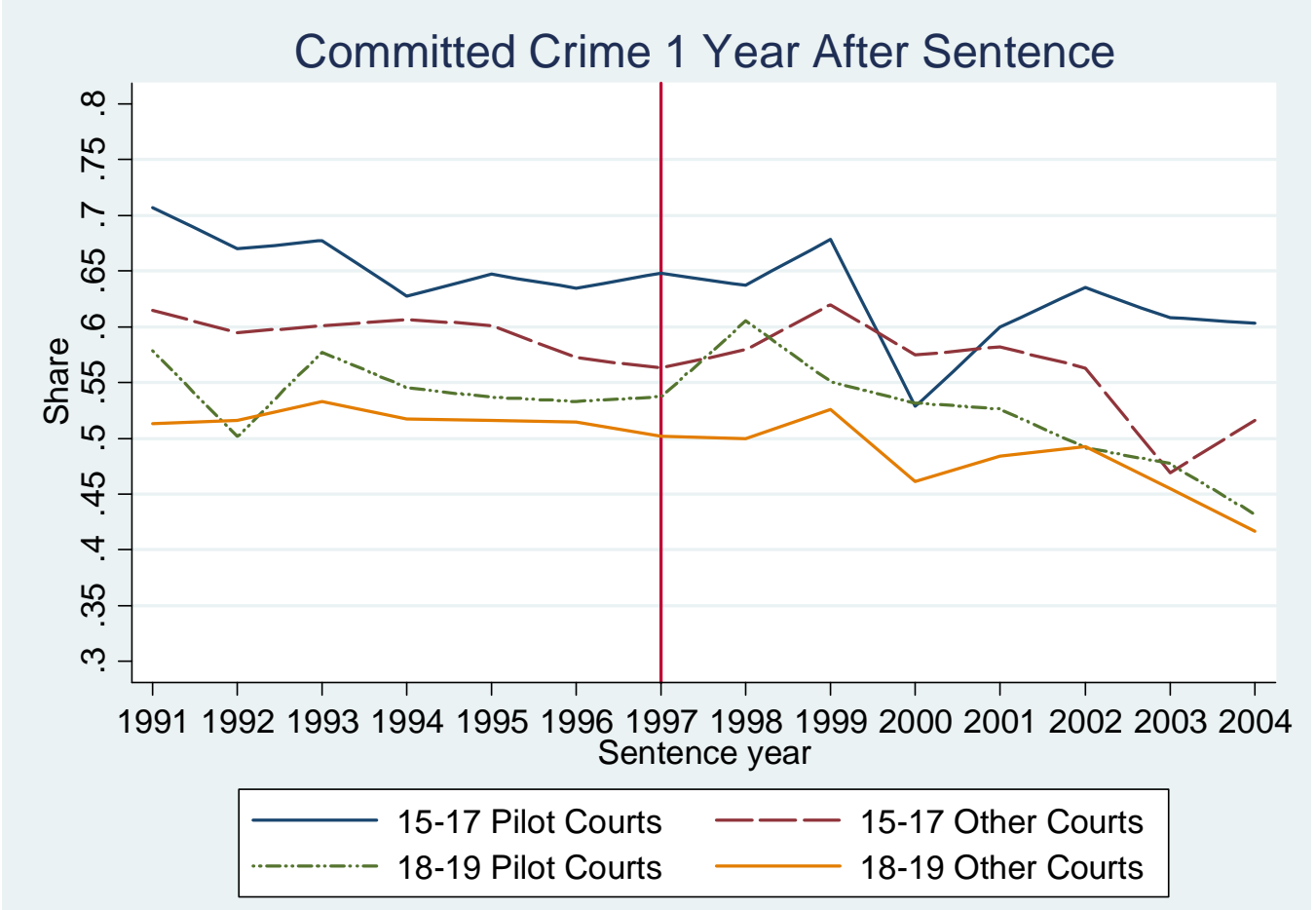

Figure A5: Share of offenders that committed a new crime within one year after the sentence: Propensity score pre-screened sample

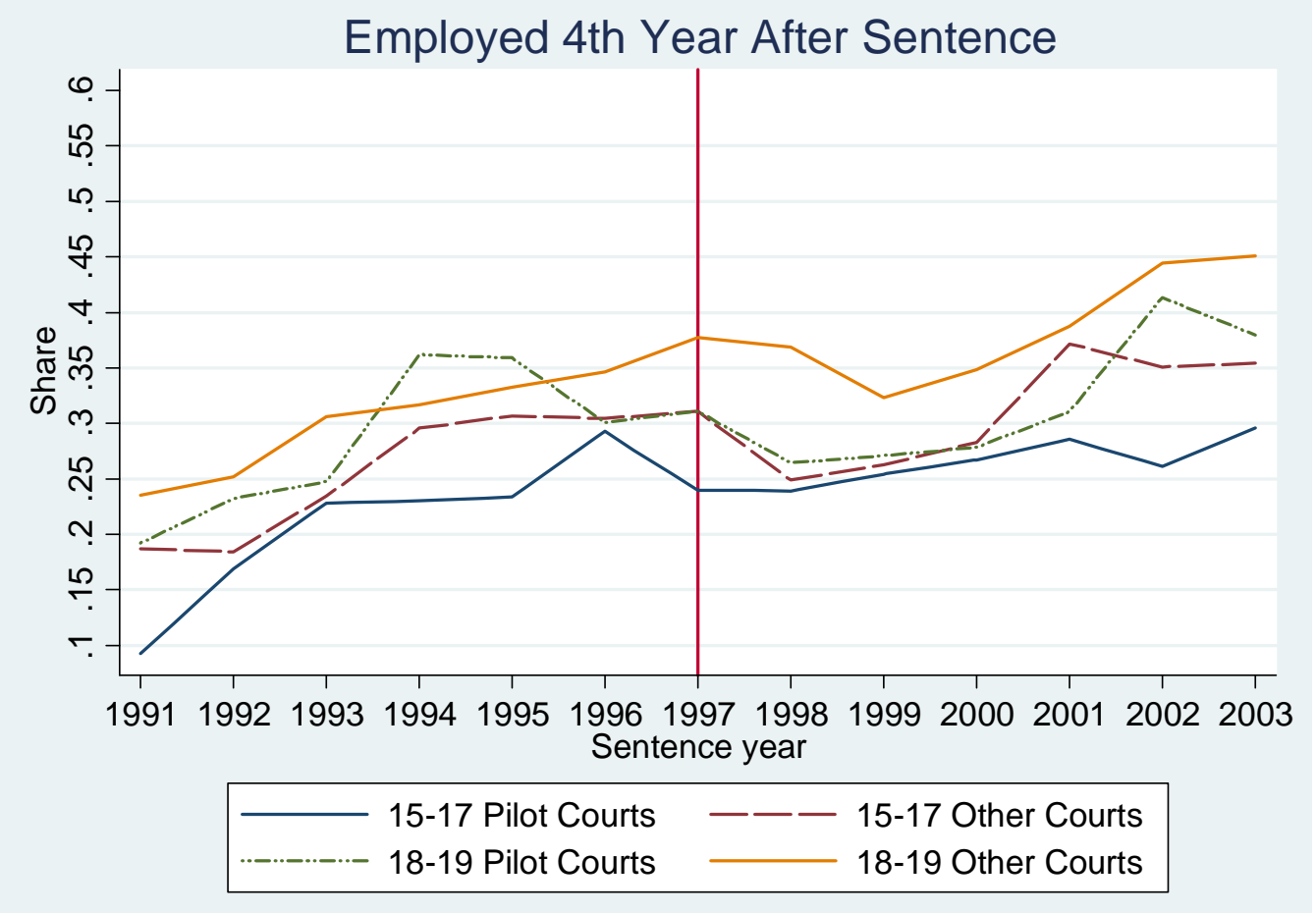

Figure A6: Share of offenders that committed new crime within one year after the sentence: Propensity score pre-screened sample 


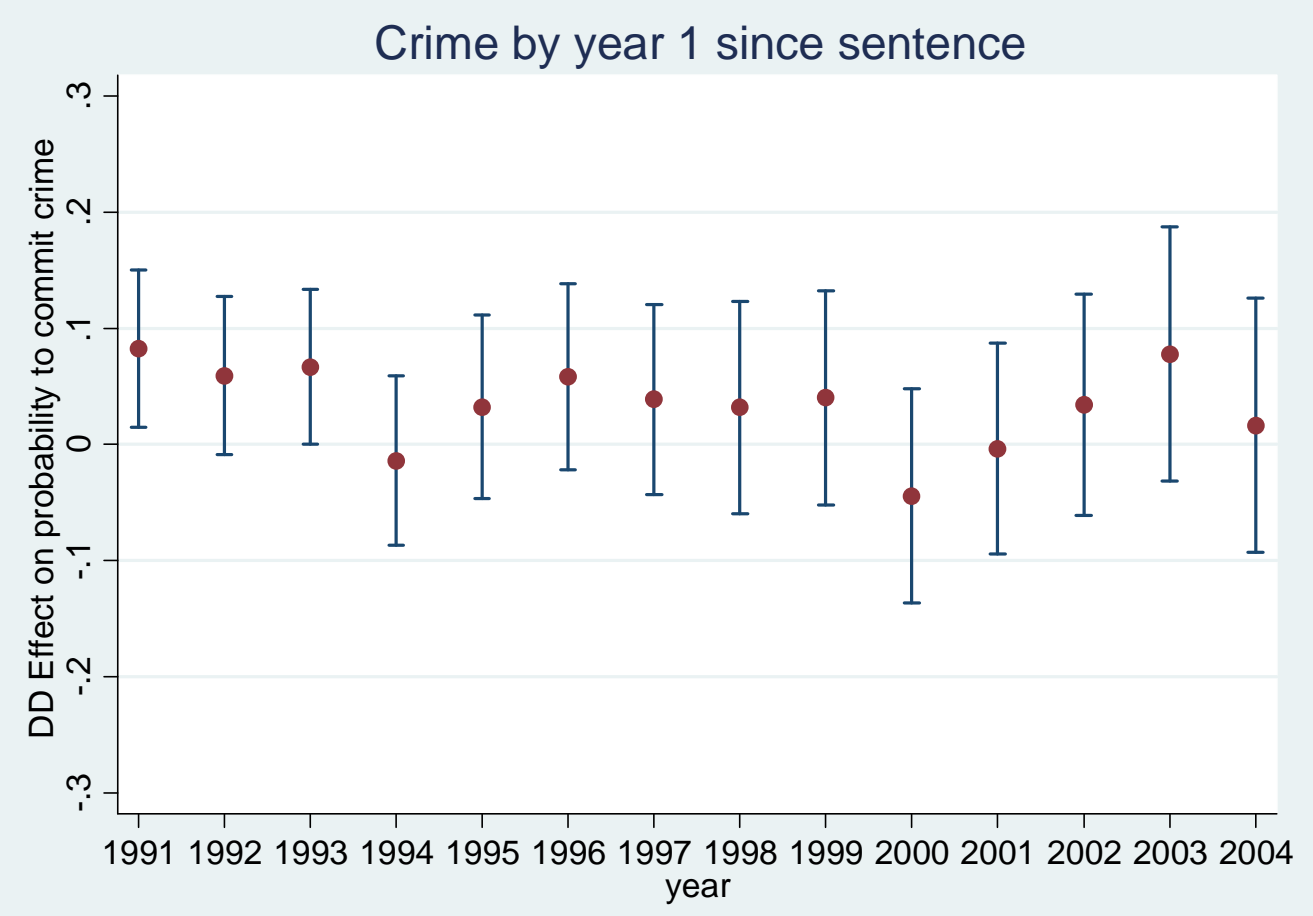

*Notes: Figure plots the pilot *year interaction in a model that estimates the effect on the reoffending probability using data for 15-17 year old offenders. For propensity score prescreening see notes in table A3.

Figure A7: The difference-in-differences estimate on the effect of eligibility on crime within one year after sentence by year: Propensity score pre-screened sample 


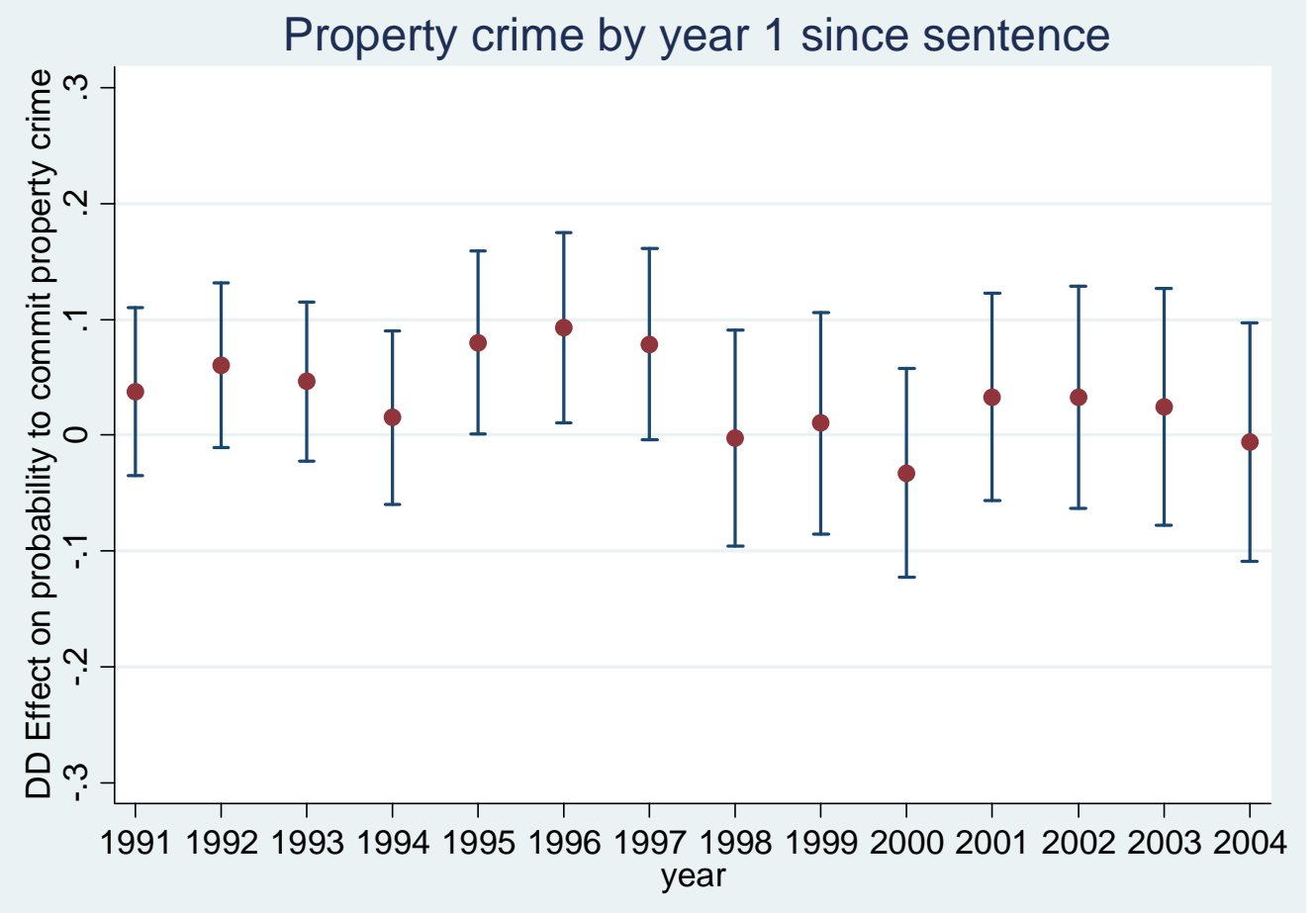

*Notes: Figure plots the pilot *year interaction in a model that estimates the effect on the reoffending probability using data for 15-17 year old offenders. For propensity score prescreening see notes in table A3.

Figure A8: The difference-in-differences estimate on the effect of eligibility on property crime within one year after sentence by year: Propensity score pre-screened sample 
Table A1: Sample Means of the Outcome Variables

\begin{tabular}{|c|c|c|c|c|c|c|}
\hline \multirow{2}{*}{$\begin{array}{l}\text { Differences-in-differences } \\
\text { sample ( } 15 \text {-17 year olds) }\end{array}$} & \multicolumn{6}{|c|}{ Follow up period } \\
\hline & Year 1 & Year 2 & Year 3 & Year 4 & Year 5 & Year 6 \\
\hline \multicolumn{7}{|c|}{ Crime related outcomes } \\
\hline Any crime by the year & 0.562 & 0.699 & 0.762 & 0.798 & 0.822 & 0.837 \\
\hline Property crime by the year & 0.398 & 0.519 & 0.582 & 0.623 & 0.655 & 0.674 \\
\hline Violent crime by the year & 0.163 & 0.257 & 0.324 & 0.374 & 0.412 & 0.442 \\
\hline Other crime by the year & 0.356 & 0.519 & 0.605 & 0.664 & 0.700 & 0.724 \\
\hline Observations & 10,450 & 10,450 & 10,450 & 9,942 & 9,427 & 8,829 \\
\hline \multicolumn{7}{|l|}{ Labor market outcomes } \\
\hline Post-compulsory degree & 0.084 & 0.134 & 0.175 & 0.198 & 0.219 & 0.236 \\
\hline Employed & 0.155 & 0.184 & 0.238 & 0.280 & 0.316 & 0.348 \\
\hline Unemployed & 0.317 & 0.343 & 0.326 & 0.298 & 0.274 & 0.260 \\
\hline Not participating & 0.208 & 0.226 & 0.251 & 0.274 & 0.287 & 0.282 \\
\hline Annual Income & 3247 & 4080 & 5197 & 6324 & 7261 & 7944 \\
\hline Observations & 10,372 & 10,306 & 10,211 & 9,628 & 9,064 & 8,423 \\
\hline \multirow{2}{*}{$\begin{array}{l}\text { Triple differences sample } \\
\text { (15-19 year olds) }\end{array}$} & \multicolumn{6}{|c|}{ Follow up period } \\
\hline & Year 1 & Year 2 & Year 3 & Year 4 & Year 5 & Year 6 \\
\hline \multicolumn{7}{|c|}{ Crime related outcomes } \\
\hline Any crime & 0.494 & 0.628 & 0.691 & 0.732 & 0.760 & 0.780 \\
\hline Property crime & 0.326 & 0.432 & 0.489 & 0.532 & 0.565 & 0.589 \\
\hline Violent crime & 0.134 & 0.216 & 0.273 & 0.318 & 0.353 & 0.381 \\
\hline Other crime & 0.325 & 0.472 & 0.550 & 0.607 & 0.645 & 0.673 \\
\hline Observations & 28,620 & 28,620 & 28,620 & 26,692 & 24,759 & 22,771 \\
\hline \multicolumn{7}{|l|}{ Labor market outcomes } \\
\hline$\overline{\text { Post-compulsory degree }}$ & 0.178 & 0.213 & 0.244 & 0.263 & 0.281 & 0.298 \\
\hline Employed & 0.204 & 0.258 & 0.308 & 0.340 & 0.364 & 0.384 \\
\hline Unemployed & 0.343 & 0.338 & 0.310 & 0.295 & 0.294 & 0.299 \\
\hline Not participating & 0.208 & 0.216 & 0.228 & 0.237 & 0.232 & 0.223 \\
\hline Income & 4597 & 5878 & 7089 & 8029 & 8909 & 9740 \\
\hline Observations & 28,379 & 28,155 & 27,942 & 25,829 & 23,758 & 21,648 \\
\hline
\end{tabular}

*Notes: Income is annual real income (in 2000 euros). Other crimes include "crime against law or order", traffic crimes, and alcohol and drug related crimes. Differences-in differences sample consists of young (aged 15-17 at the time of crime) male offenders sentenced to prison, probation or juvenile punishment for all crimes (except sex crimes) in 19912004. Triple differences sample consists of 15-19-year olds (at the time of crime) male offenders sentenced to prison, probation or juvenile punishment for all crimes (except sex crimes) in 1991-2004. 
Table A2: Effect of background characteristics on the probability of juvenile punishment among the eligible (15-17 year old sentenced in pilot court districts)

\begin{tabular}{lll}
\hline VARIABLES & $\begin{array}{l}\text { Probit marginal } \\
\text { effect }\end{array}$ & Stand. err. \\
\hline Parent sentenced & 0.080 & $(0.082)$ \\
Father more than compl. edu & 0.087 & $(0.085)$ \\
Mother more than compl. edu & -0.067 & $(0.081)$ \\
Lives with mother & 0.167 & $(0.146)$ \\
Lives with father & -0.149 & $(0.106)$ \\
Employed_1 & -0.098 & $(0.123)$ \\
Mother dead & 0.236 & $(0.343)$ \\
Father dead & $0.289 *$ & $(0.165)$ \\
Sentenced t-1 & $0.424^{* * *}$ & $(0.078)$ \\
Mother employed & -0.011 & $(0.126)$ \\
Father employed & $-0.322^{* *}$ & $(0.140)$ \\
Any sibling & -0.082 & $(0.122)$ \\
Household with children & 0.062 & $(0.161)$ \\
Mother earn cat 0 & 0.183 & $(0.230)$ \\
Mother earn cat 1 & 0.317 & $(0.216)$ \\
Mother earn cat 2 & 0.313 & $(0.191)$ \\
Mother earn cat 3 & 0.218 & $(0.144)$ \\
Father earn cat 0 & -0.189 & $(0.245)$ \\
Father earn cat 1 & 0.153 & $(0.247)$ \\
Father earn cat 2 & -0.007 & $(0.237)$ \\
Father earn cat 3 & -0.112 & $(0.206)$ \\
Mother inc cat 0 & -0.219 & $(0.283)$ \\
Mother inc cat 1 & -0.017 & $(0.195)$ \\
Mother inc cat 3 & $-0.299 *$ & $(0.153)$ \\
Father inc cat 0 & -0.264 & $(0.247)$ \\
Father inc cat 1 & -0.195 & $(0.226)$ \\
Father inc cat 2 & 0.008 & $(0.217)$ \\
Father inc cat 3 & 0.055 & $(0.192)$ \\
Property & -0.132 & $(0.128)$ \\
Violent & -0.193 & $(0.139)$ \\
Traffic & -0.081 & \\
Against Order & 0.079 & \\
\hline Observations & 1,765 & \\
\hline & $0.262)$ \\
\hline
\end{tabular}

*Notes: Dependent variable: Probability of juvenile punishment. Sample consists of 15-17 year old male offenders in pilot locations in 1997-2004. Excluded earnings category is the highest quartile. Excluded crime category is "drug and alcohol related crimes". Standard errors in parentheses. ${ }^{* * *} \mathrm{p}<0.01,{ }^{* *} \mathrm{p}<0.05,{ }^{*} \mathrm{p}<0.1$ 
Table A3: Difference-in-Differences Estimates for the Effect of Juvenile Punishment on Crime and Labor Market Outcomes. Propensity score pre-screened sampl.

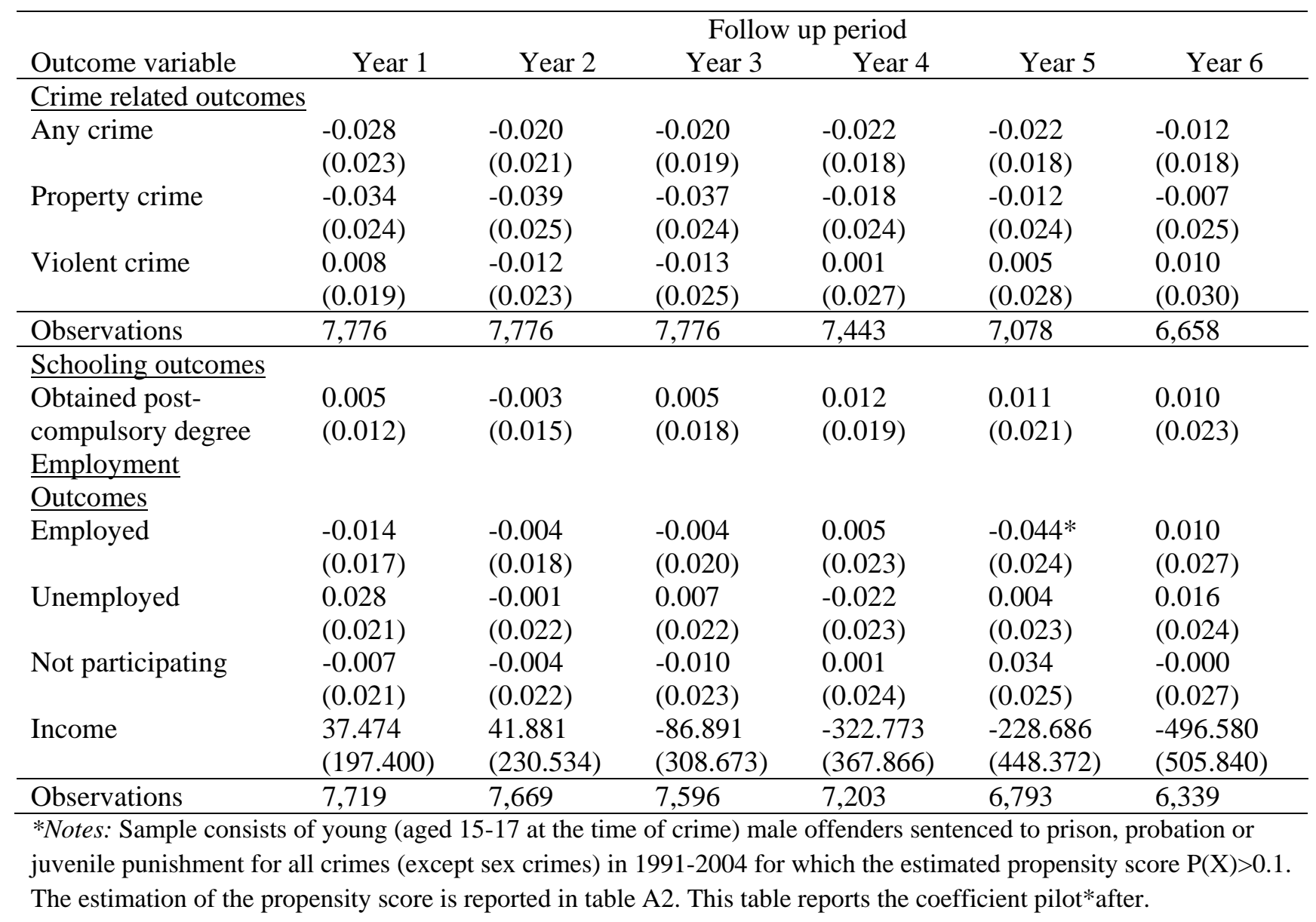


Table A4: Triple Differences Estimates for the Effect of Juvenile Punishment on Crime and Labor Market Outcomes. Propensity score pre-screened sample

\begin{tabular}{|c|c|c|c|c|c|c|}
\hline \multirow[b]{2}{*}{ Outcome variable } & \multicolumn{6}{|c|}{ Follow up period } \\
\hline & Year 1 & Year 2 & Year 3 & Year 4 & Year 5 & Year 6 \\
\hline \multicolumn{7}{|l|}{ Crime related outcomes } \\
\hline Any crime & $\begin{array}{l}-0.025 \\
(0.029)\end{array}$ & $\begin{array}{l}-0.026 \\
(0.027)\end{array}$ & $\begin{array}{l}-0.031 \\
(0.025)\end{array}$ & $\begin{array}{l}-0.037 \\
(0.024)\end{array}$ & $\begin{array}{l}-0.035 \\
(0.024)\end{array}$ & $\begin{array}{l}-0.024 \\
(0.024)\end{array}$ \\
\hline Property crime & $\begin{array}{l}-0.024 \\
(0.029)\end{array}$ & $\begin{array}{l}-0.019 \\
(0.030)\end{array}$ & $\begin{array}{l}0.000 \\
(0.029)\end{array}$ & $\begin{array}{l}0.013 \\
(0.029)\end{array}$ & $\begin{array}{l}0.029 \\
(0.030)\end{array}$ & $\begin{array}{l}0.013 \\
(0.031)\end{array}$ \\
\hline Violent crime & $\begin{array}{l}0.011 \\
(0.022)\end{array}$ & $\begin{array}{l}-0.015 \\
(0.027)\end{array}$ & $\begin{array}{l}-0.044 \\
(0.029)\end{array}$ & $\begin{array}{l}-0.030 \\
(0.031)\end{array}$ & $\begin{array}{l}-0.026 \\
(0.033)\end{array}$ & $\begin{array}{l}-0.024 \\
(0.035)\end{array}$ \\
\hline Observations & 20,886 & 20,886 & 20,886 & 19,607 & 18,288 & 16,913 \\
\hline$\underline{\text { Schooling outcomes }}$ & & & & & & \\
\hline $\begin{array}{l}\text { Obtained post- } \\
\text { compulsory degree } \\
\text { Employment Outcomes }\end{array}$ & $\begin{array}{l}0.034 * * \\
(0.014)\end{array}$ & $\begin{array}{l}0.025 \\
(0.018)\end{array}$ & $\begin{array}{l}0.033^{*} \\
(0.020)\end{array}$ & $\begin{array}{l}0.033 \\
(0.022)\end{array}$ & $\begin{array}{l}0.025 \\
(0.024)\end{array}$ & $\begin{array}{l}0.024 \\
(0.026)\end{array}$ \\
\hline$\overline{\text { Employed }}$ & $\begin{array}{l}0.008 \\
(0.022)\end{array}$ & $\begin{array}{l}0.019 \\
(0.024)\end{array}$ & $\begin{array}{l}0.039 \\
(0.026)\end{array}$ & $\begin{array}{l}0.047 * \\
(0.028)\end{array}$ & $\begin{array}{l}-0.015 \\
(0.030)\end{array}$ & $\begin{array}{l}0.032 \\
(0.033)\end{array}$ \\
\hline Unemployed & $\begin{array}{l}0.043 \\
(0.027)\end{array}$ & $\begin{array}{l}0.023 \\
(0.028)\end{array}$ & $\begin{array}{l}0.010 \\
(0.028)\end{array}$ & $\begin{array}{l}0.009 \\
(0.029)\end{array}$ & $\begin{array}{l}-0.000 \\
(0.029)\end{array}$ & $\begin{array}{l}0.032 \\
(0.031)\end{array}$ \\
\hline Not participating & $\begin{array}{l}-0.051^{*} \\
(0.026)\end{array}$ & $\begin{array}{l}-0.039 \\
(0.027)\end{array}$ & $\begin{array}{l}-0.050 * \\
(0.027)\end{array}$ & $\begin{array}{l}-0.034 \\
(0.030)\end{array}$ & $\begin{array}{l}0.014 \\
(0.030)\end{array}$ & $\begin{array}{l}-0.024 \\
(0.032)\end{array}$ \\
\hline Income & $\begin{array}{l}387.912 \\
(263.027)\end{array}$ & $\begin{array}{l}435.482 \\
(329.469)\end{array}$ & $\begin{array}{l}641.680 \\
(399.684)\end{array}$ & $\begin{array}{l}201.351 \\
(467.199)\end{array}$ & $\begin{array}{l}267.814 \\
(579.412)\end{array}$ & $\begin{array}{l}236.186 \\
(637.669) \\
\end{array}$ \\
\hline Observations & 20,706 & 20,528 & 20,364 & 18,939 & 17,504 & 16,031 \\
\hline
\end{tabular}

